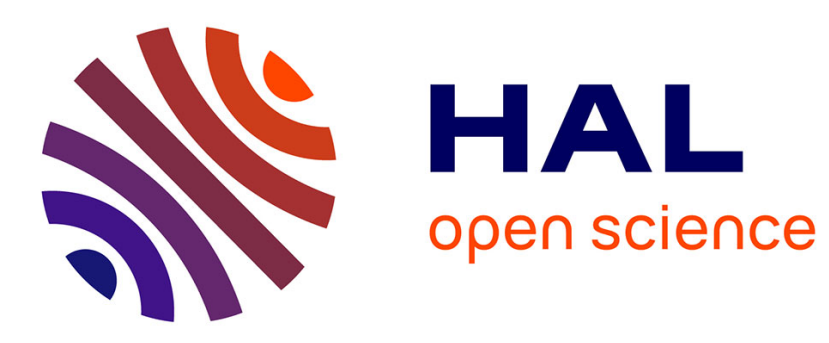

\title{
Pythium insidiosum: An overview
}

Wim Gaastra, Len J.A. Lipman, Arthur W.A.M. de Cock, Tim K. Exel,

Raymond B.G. Pegge, Josje Scheurwater, Raquel Vilela, Leonel Mendoza

\section{To cite this version:}

Wim Gaastra, Len J.A. Lipman, Arthur W.A.M. de Cock, Tim K. Exel, Raymond B.G. Pegge, et al.. Pythium insidiosum: An overview. Veterinary Microbiology, 2010, 146 (1-2), pp.1. 10.1016/j.vetmic.2010.07.019 . hal-00636632

\section{HAL Id: hal-00636632 \\ https://hal.science/hal-00636632}

Submitted on 28 Oct 2011

HAL is a multi-disciplinary open access archive for the deposit and dissemination of scientific research documents, whether they are published or not. The documents may come from teaching and research institutions in France or abroad, or from public or private research centers.
L'archive ouverte pluridisciplinaire HAL, est destinée au dépôt et à la diffusion de documents scientifiques de niveau recherche, publiés ou non, émanant des établissements d'enseignement et de recherche français ou étrangers, des laboratoires publics ou privés. 


\section{Accepted Manuscript}

Title: Pythium insidiosum: An overview

Authors: Wim Gaastra, Len J.A. Lipman, Arthur W.A.M. De Cock, Tim K. Exel, Raymond B.G. Pegge, Josje Scheurwater, Raquel Vilela, Leonel Mendoza

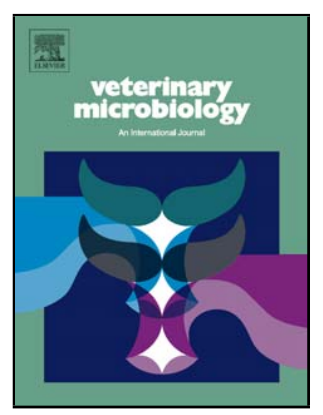

PII:

S0378-1135(10)00354-8

DOI: doi:10.1016/j.vetmic.2010.07.019

Reference: VETMIC 4975

To appear in:

VETMIC

Received date:

20-4-2010

Revised date:

$19-7-2010$

Accepted date:

$19-7-2010$

Please cite this article as: Gaastra, W., Lipman, L.J.A., De Cock, A.W.A.M., Exel, T.K., Pegge, R.B.G., Scheurwater, J., Vilela, R., Mendoza, L., Pythium insidiosum: An overview, Veterinary Microbiology (2010), doi:10.1016/j.vetmic.2010.07.019

This is a PDF file of an unedited manuscript that has been accepted for publication. As a service to our customers we are providing this early version of the manuscript. The manuscript will undergo copyediting, typesetting, and review of the resulting proof before it is published in its final form. Please note that during the production process errors may be discovered which could affect the content, and all legal disclaimers that apply to the journal pertain. 
Title: Pythium insidiosum: An overview

2

3 Type of article: Review

4 Authors: Wim Gaastra ${ }^{1}$, Len J. A. Lipman ${ }^{2 *}$, Arthur W.A.M. De Cock ${ }^{3}$, Tim K. Exel ${ }^{2}$,

5 Raymond B.G. Pegge ${ }^{2}$, Josje Scheurwater ${ }^{2}$, Raquel Vilela ${ }^{4}$, Leonel Mendoza ${ }^{4,5}$.

6

7

${ }^{1}$ Department of Infectious Diseases and Immunology, Faculty of Veterinary Medicine,

8 Utrecht University, The Netherlands.

9

$10{ }^{2}$ Division of Public Health and Food Safety, Institute for Risk Assessment Sciences, Utrecht

11 University, The Netherlands.

12

13

${ }^{3}$ CBS-KNAW, Fungal Biodiversity Centre, Utrecht, The Netherlands

14

15

${ }^{4}$ Biomedical Laboratory Diagnostics, Michigan State University, East Lansing, USA.

16

17

${ }^{5}$ Microbiology and Molecular Genetics, Michigan State University, East Lansing, USA. 18

*Corresponding Author: Division of Public Health and Food Safety, Institute for Risk

Assessment Sciences, Utrecht University, Yalelaan 2, 3508 TD Utrecht, The Netherlands, Tel.

31-302535342; E-mail: L.J.A.Lipman@iras.uu.nl

22

23

24

25

26

27

28

29

30

31

32

33

34

35

36

37

38

Keywords: Pythium insidiosum, pythiosis, oomycete, immunotherapy. 


\section{Abstract}

Pythium insidiosum is an oomycete pathogenic in mammals. The infection occurs mainly in tropical and subtropical areas, particularly in horses, dogs and humans. Infection is acquired through small wounds via contact with water that contains motile zoospores or other propagules (zoospores or hyphae). The disease, though described as emerging has in fact already been described since 1884. Depending on the site of entry, infection can lead to different forms of pythiosis i.e. a cutaneous, vascular, ocular, gastrointestinal and a systemic form, which is rarely seen. The infection is not contagious; no animal-animal or animalhuman transmission has been reported so far. Therapy includes radical surgery, antifungal drugs, immunotherapy or a combination of these therapies. The prevention to contract the disease in endemic areas is difficult. Avoiding stagnant waters could be of help, although the presence of $P$. insidiosum on grass and soil in enzootic areas renders this practice useless.

\section{Introduction}

Pythium insidiosum is the only etiologic agent of pythiosis in mammals. Most cases of pythiosis have been reported in dogs, horses and humans. Only sporadic cases in other animals, such as calves (Pérez et al., 2005), cats (Miller et al., 1985, Thomas and Lewis, 1998, Rakich et al., 2005,), sheep (Miller et al., 1985, Tabosa et al., 2004, Santurio et al., 2008), a bird (Pesavento et al., 2008) and tropical animals held in captivity (Camus et al., 2004, Wellahan et al., 2004, Buergelt et al., 2006) are known. Pythiosis is a rarely occurring, nontransmissible disease traditionally found in tropical, subtropical and temperate regions (de Cock et al. 1987, Mendoza et al., 1993, Mendoza, 2005). Recently however, pythiosis was also observed in California and Arizona, where the climate does not fit this description. These observations might indicate that the environmental niche for $P$. insidiosum is expanding, probably as a consequence of environmental changes like deliberate flooding of rice fields or irrigated landscape development (Berryessa et al., 2008, White et al., 2008). In Thailand pythiosis is considered to be endemic. Pythiosis in humans is life-threatening with high rates of morbidity and mortality, especially in regions with a lack of tools for early diagnosis and effective treatment. While pythiosis is often described as an emerging disease (Laohapensang, et al., 2009), the disease was already described in 1884 by British veterinarians working with horses in India (Smith, 1884).

The agent causing the disease (at that time named Hyphomycosis destruens equi) was isolated for the first time in 1901 by Dutch scientists working with horses in Indonesia and 
again in 1924 by another Dutch (de Haan and Hoogkamer, 1901, Witkamp 1924). The disease has been known under various other names: bursattee or bursatte (derived from the Indian word Burus, Bursator or Bausette which means rainy season), espundia (Latin America), equine phycomycosis (Australia, USA), granular dermatitidis (Japan), hyphomycosis destruens equi (Indonesia), leeches (USA), swamp cancer (Australia, USA) and summer sores (Australia, Latin America, USA) (Kerr, 1829, Fish, 1895, Witkamp, 1924, Gonzalez and Ruiz, 1975, Ichitani and Amemiya, 1980).

The fungus-like nature of the causal agent of the disease was probably first reported by Smith (1884) and Drouin (1896). By lack of sporulation the agent could not be identified and it did not get a name until 1961 when Bridges and Emmons (1961) named the organism Hyphomyces destruens. This name was derived from the name of the disease Hyphomycosis destruens which was introduced by de Haan and Hoogkamer (1901) and later extended to Hyphomycosis destruens equi by De Haan (1902). However, the name H. destruens was not validly published and lacked a Latin description and the designation of a type. Bridges and Emmons called the disease phycomycosis because they thought the organism was a zygomycete, probably Mortierella. Austwick and Copland (1974) observed zoospore development when cultures grown on Sabouraud dextrose agar were transferred to an aqueous medium. They concluded that the $H$. destruens actually belonged to the Oomycete genus Pythium. Based on this discovery, Chandler et al (1980) proposed the term pythiosis for the disease. In 1980, Ichitani and Amemiya (1980) isolated a Pythium sp. from a diseased horse and found it to be morphologically similar to Pythium gracile Schenk (Amemiya, 1982). However, $P$. gracile is a poorly described species of which the identity cannot be verified. Moreover, it was isolated from algae in Germany, where pythiosis does not occur. The oomycete was formally described as Pythium insidiosum when sexual sporulation was observed by De Cock et al (1987). Almost simultaneously Shipton (1987) proposed the binomial Pythium destruens for a strain isolated from an Australian horse with pythiosis. Based on priority $P$. destruens is now considered a synonym of P. insidiosum (Mendoza and Marin, 1989).

Pythium insidiosum mainly occurs in surface water amongst others in standing inland waters and occasionally in soil (Mendoza et al., 1993, Mendoza et al., 1996). Not much is known about the ecological preference of $P$. insidiosum, but the presence of water which induces the formation of zoospores seems to be a prerequisite (Supabandhu et al., 2008). Since $P$. insidiosum usually occurs under wetland conditions, more cases are seen after heavy rain or floods (Miller, 1983, Miller and Campbell, 1983, Mendoza et al., 1993). Other risk 
108 factors for developing pythiosis have not yet been identified. Floods after heavy rain have

109 been incriminated as one of the natural resources used by $P$. insidiosum to expand its

110 ecological niche to new areas (Mendoza et al., 1993, Supabandhu et al., 2008 ).

111 Phylogenetic analysis has shown that Pythium spp. are closer related to diatomeae and algae

112 than to true fungi (Kwon-Chung, 1994, Hudspeth et al., 2000, Martin; 2000). Pythium spp.

113 belong to the kingdom Stramenopila, the Phylum Oomycota, the order Peronosporales and the

114 family Pythiaceae (Alexopoulos et al., 1996). Pythium spp have also been classified by others

115 in the kingdom Chromista, the Phylum Pseudofungi, the class Oomycetes, the order Pythiales

116 and the family Pythiaceae (Mendoza et al., 1996). In the most recent classification (Dick,

117 2001), P. insidiosum as a member of the genus Pythium is classified in the kingdom

118 Straminipila, class Peronosporomycetes (= Oomycetes), order Pythiales and family

119 Pythiaceae. This classification, however, was not yet based on DNA sequence data and may

120 change in the near future.

\section{The Agent}

Microscopically $P$. insidiosum develops mycelium like fungi, but it is not a true fungus, since its cell walls do not contain chitin but are composed of cellulose and B-glucans, its cytoplasmic membrane lacks ergosterol, the thallus is diploid and coenocytic, the sexual process is oogamy and the organism develops biflagellate zoospores in wet environments

127 (Alexopoulos et al, 1996). Zoospores are single nucleated cells without a cell wall that can 128 swim with the help of two flagella; a tinsel (anterior) flagellum and a whiplash (posterior)

129 flagellum. The posterior flagellum is thought to be responsible for the movement of the zoospore through water, the antherior flagellum functions as a rudder. Zoospores swim in a

131 helical or spiral pattern interrupted by random changes of direction. Zoospores cannot divide or multiply (Walker and van West, 2007). The zoospores are considered to be the infective

133 propagules, they show chemotaxis and become encysted once they come in contact with

134 either decaying or injured plant tissue (there is no evidence that healthy plant tissue has a

135 similar effect). Injured tissue of a mammalian host that enters the ecosystem of $P$. insidiosum

136 exerts the same effect. A glycoprotein secreted on the surface of the encysted zoospores

137 allows adhesion to the injured tissue (Estrada-Garcia et al., 1990, Mendoza et al., 1993,

138 Mendoza et al., 1996).

139 Pythium insidiosum infections occur mostly in apparently healthy humans and animals

140 (Thianprasit, 1990, Mendoza et al., 1996, Thomas and Lewis, 1998, Grooters, 2003,

141 Mendoza, 2005). Pythiosis occurs in regions of Southeast Asia (India, Indonesia, Japan, 
142 Korea, New Guinea, and Thailand) (Ichitani and Amemiya, 1982, Thianprasit, 1986, 1990,

143 Sohn et al., 1996), eastern coastal Australia and New Zealand (Miller, 1983, Triscott et al.,

144 1993, Murdoch and Parr, 1997), South America (Argentina, Brazil, Colombia, Venezuela)

145 (Gonzalez and Ruiz, 1975, Mendoza, 2005), Costa Rica (Mendoza and Alfaro, 1986, Alfaro

146 and Mendoza, 1990), Guatemala (Mendoza et al., 1996), Haiti (Virgile et al., 1993), Panama

147 and Nicaragua (Mendoza and Alfaro, 1986) and North America, Mexico and the United States

148 (Miller, 1983, Grooters, 2003, Mendoza, 2005). In the USA it occurs most often in the Gulf

149 coast states but has also been identified in other states (Mendoza, 2005, Grooters, 2007). The

150 first case of pythiosis from Africa (Mali) was reported in a dog (Rivierre et al., 2005). This

151 case was confirmed by molecular sequencing, placing the African strain in a separate taxon

152 from the American and Asian clusters reported by Schurko et al., (2003a).

153 Pythium insidiosum is well adapted to the body temperature of its mammalian hosts. It

154 has an optimum and maximum temperature for growth of $34-36^{\circ}$ and $40-45^{\circ}$ respectively (De

155 Cock et al., 1987). It grows well on various artificial media when incubated at $25^{\circ}$ or $37^{\circ} \mathrm{C}$.

156 Sabouraud agar (Witkamp, 1924, 1925, De Cock et al., 1987), vegetable extract agar, peptone

157 yeast glucose agar and potato flakes agar all can be used (de Cock et al., 1987, Shipton, 1987,

158 Grooters et al., 2002b). On Sabouraud agar P. insidiosum grows in submerged, white to

159 colourless colonies, which have an irregular radiate pattern (de Cock et al., 1987, Mendoza et

160 al., 1993, 1996) (Fig. 1A). Zoospores are only developed in water cultures; they are

161 stimulated by the presence of ions such as $\mathrm{K}^{+}, \mathrm{Ca}^{2+}, \mathrm{Mg}^{2+}$ and chemically attracted by plant

162 material, animal hairs or pieces of animal tissue (Austwick and Copland, 1974, Shipton, 1987,

163 Mendoza and Prendas, 1988, Chaiprasert et al., 1990, Mendoza et al., 1993). While in some

164 oomycetes, zoospore formation can occur within minutes and is considered one of the fastest

165 developmental processes in any biological system (Walker and van West, 2007), in

166 P.insidiosum zoospore formation can take one hour or more (Mendoza and Prendas, 1988). $P$.

167 insidiosum does not need a susceptible mammalian host for its survival or propagation since it

168 is able to survive and multiply in its natural environment on decaying plants (Mendoza et al.

169 1993).

171 Molecular Phylogeny of Pythium insidiosum.

172 The first reports showing that $P$. insidiosum is a unique oomycetous pathogen of

173 mammals came from molecular phylogenetic studies of several Pythium species (Martin,

174 2000; Lévesque and de Cock, 2004). Lévesque and de Cock (2004) divided Pythium species

175 in at least 10 different phylogenetic groups (designated A to K). $P$. insidiosum is found in 
group $\mathrm{C}$ together with $P$. grandiosporangium. Grouping of $P$. insidiosum together with this marine saprotrophic microbe is intriguing since $P$. insidiosum is a fresh water organism. Moreover, the two species are significantly different with regard to morphology and growth/temperature relationships. The clustering of the two in one clade is more likely to be the consequence of long range attraction then of a genuine close relationship.

Schurko et al (2003a, b) observed heterogeneity in ribosomal DNA sequences (IGS and ITS) among isolates of $P$. insidiosum which were correlated to geographic origin but not to host. They distinguished three different groups: clade I is comprised of isolates from North, Central and South America, clade II consists of isolates from Asia and Australia, whereas clade III contains isolates from Thailand and the USA. Clade I and II are closely related but Clade III is significantly different from the other two. Moreover, one isolate in clade III from Tremarctos ornatus is deviating from the other strains in this clade. Therefore it was hypothesized that the members of the third group might represent a new species, but they were not treated as such.

The ability of $P$. insidiosum to develop appressoria and the chemotaxis of its zoospores to plant tissue suggests that this pathogen took advantage of these ancestral features and adapted them to a lifestyle as a mammalian parasite. When P. insidiosum acquired the pathogenic attributes to invade mammals, hopefully can be answered after completion of its complete genome sequence. Several genome sequencing projects of plant pathogenic oomycetes are already finished and some others are underway. To our knowledge this is not yet the case for $P$. insidiosum.

\section{Epidemiology and pathogenesis}

Zoospores show a marked chemotaxis towards animal hair, wounds, other damaged skin parts or intestinal mucosa (De Cock et al 1987, Mendoza et al 1993). Upon microscopy, adhesion of zoospores to the cut edges of skin but hardly to undamaged tissue was observed (Mendoza et al., 1993, Grooters, 2003). The location of the lesions is therefore directly related to the parts of the body that were in direct contact with water containing zoospores of $P$. insidiosum. For example, in horses lesions are seen especially on the legs and ventral parts of the abdomen. Lesions caused by punctures and insect bites can also be a "port d'entree" for Pythium insidiosum (Mendoza et al., 1993, Mendoza et al., 1996, Rees, C.A., 2004). Insect bites are of interest from an epidemiological point of view since Schurko et al., (2003a) identified an isolate from an infected larva of Culex quinquefasciatus (a widespread tropical mosquito) in India as $P$. insidiosum. This suggests that $P$.insidiosum has the ability to invade 
210 insects and thus the possibility of transmission through infected mosquitoes is of concern,

211 especially in the tropical regions where mosquitoes are prevalent.

212 Once the zoospores are in contact with mammalian or plant tissue (in wet

213 environments) they encyst on the surface of the injured tissue(s). The encysted zoospores

214 secrete a sticky amorphous glycoprotein that mediates the adhesion of zoospores to tissue

215 before they enter the tissue (Mendoza, et al., 1993, Mendoza et al., 1996). The encysted

216 zoospores stimulated by the host's body temperature develop a germ tube (hypha) that

217 extends from the zoospores into the infected tissue and later can also infiltrate blood vessels

218 (humans), which makes spreading within the body tissues easier. The disease can also be 219 acquired through traumatic lesions and contact with hyphae of $P$. insidiosum (Mendoza et al., 220 1990). The invasion of blood vessels can lead to thrombosis and invasion of large arteries 221 (Imwidthaya, 1994, Thitithanyanont, 1998, Krajaejun et al., 2006, Pupaibool, et al., 2006, 222 Laohapensang et al., 2009). In addition to $P$. insidiosum host colonization by invasive growth, 223 the secretion of proteases and the exertion of mechanical force by the tips of the elongating 224 hyphae have been implicated as putative virulence factors (Shipton, 1987, Ravishankar et al., 225 2001). For $P$. insidiosum this force has been measured and compared with the resistance of 226 human and equine skin to needle insertion. The data show that a significant reduction in tissue 227 strength has to be obtained by the action of proteases, before penetration of the tissue by 228 hyphae can take place (Ravishankar et al., 2001, MacDonald et al., 2002, Davis et al., 2006). 229 All three tested strains of P.insidiosum secrete three or more proteases of different molecular 230 weight. Two of them were present in the three strains. The specificity of the proteases is not 231 known, but inhibition experiments identified them as serine proteases (Davis et al., 2006).

232 Secretion of proteases seems to be a general feature of pathogenic oomycetes (Bangyeekhun 233 et al., 2001, Torto-Alalibo et al., 2005). Pythiosis progresses rapidly and if not treated in the 234 early stages can become life threatening in both humans and animals. So far zoonotic 235 properties have not been demonstrated for $P$. insidiosum.

\section{Clinical signs in animals}

Pythiosis has been reported in several species, but most cases occur in otherwise immunocompetent horses and dogs. In animals the infection develops in the form of a cutaneous or intestinal disease, although cases of localized lung and bone infection, as well as

241 systemic dissemination through lymph nodes have been also described (Witkamp, 1925,

242 Goad, 1984, Mendoza et al., 1988, Alfaro and Mendoza, 1990, Reis et al., 2003).

243 Horses 
244 In horses there seems to be no predisposition for breed, age or sex of the animals (Miller, 245 1983, Mendoza and Alfaro, 1986, Mendoza, 2005, White et al, 2008). In this species the cutaneous form is more prevalent whereas the intestinal form is rarely recorded (Brown and

247 Roberts 1988, Morton et al., 1991, Purcel et al., 1994). The Dutch authors (Bubberman, 1914, 248 Witkamp, 1924) describe for all their equine patients that they were apparently suffering from itching, since they were rubbing the infected area of the body against the wall of the stable or biting the wound when allowed. In some cases this lead to auto-mutilation (Mendoza et al., 1986). These authors also describe the awful smell associated with horses infected with this pathogen. Lesions in the cutaneous form often consist of large, rounded, granulomatous nodular ulcerative tissue. The lesions are tumour-like and consist of necrotic tissue, containing eosinophils and hyphae of $P$. insidiosum (Headley et al., 2002, Miller, 1983, Miller and Campbell, 1984, Mendoza and Alfaro, 1986, Chaffin, et al., 1995). The tissue and the draining fistulas contain cores of necrotic yellow-gray material referred to as "kunkers". Kunkers can vary in size, from a grain of rice, to various centimetres and can sometimes be found in bandage material (Fig. 2). Kunkers are specific for equine pythiosis and absent in other affected species (Leal et al., 2001, Mendoza et al., 1996, Mendoza, 2005). Kunkers in horses are formed by degranulation of eosinophils over the invading hyphae of $P$. insidiosum. New eosinophils degranulate over the old ones and the structural mass grows in size. In horses with chronic pythiosis the only place where the hyphae of $P$. insidiosum can be found is within kunkers. The clinical signs of a horse with pythiosis may include in addition to skin and bone lesions, lameness and enlargement of regional lymph nodes, anemia and hypoproteinemia. Both hypoproteinemia and anemia occur as a result of blood loss and loss of exudates consisting of serum and cations through large ulcerated skin lesions (Miller,1983, Mendoza and Alfaro, 1986) (Fig. 3). Intestinal pythiosis in horses is characterized by stenotic fibrous and disseminated gastrointestinal lesions (Brown and Roberts, 1988, Allison and

269 Gillis, 1990, Purcell et al., 1994).

270 Dogs

271 In dogs, in contrast to horses, the gastrointestinal form of pythiosis occurs more often than the 272 subcutaneous form (Fig. 4). The clinical symptoms include vomiting, weight loss, intermittent 273 diarrhoea and palpable masses in the abdomen (Fischer at al., 1994). Extension of the 274 infection to the pancreas, mesenteric lymph nodes and bile ducts can occur (Thomas and 275 Lewis, 1998, Grooters, 2003, Berryessa et al., 2008). Lesions may involve legs and face or 276 tail (Thomas and Lewis, 1998). Infection by P. insidiosum in dogs is more frequent in young 277 immunocompetent adults (Grooters, 2003, Grooters et al., 2003). 
278 Cats

279 Pythiosis in cats is rare and usually the lesions are confined to the skin and subcutaneous

280 tissues (Fig, 5) (Thomas and Lewis, 1998, Grooters, 2003,). Gastrointestinal infections in cats 281 were reported only recently (Rakich et al., 2005). There is no predisposition for breed, age or 282 sex (Grooters, 2003).

\section{Cattle}

284 Pythiosis in cattle usually occurs during the rainy season in subtropical areas. It is considered 285 a sporadic disease in this species. However, an epizootic event involving more than 60 calves 286 was reported in Venezuela (Pérez et al., 2005). The disease occurs more frequently on the 287 limbs with pruritus and claudication. Tumor-like masses with fistules and ulcerated tissue of 288 the limbs is common. The hyphae are usually localized at the centre of eosinophilic 289 granulomas. The affected areas are extremely painful and most animals cannot stand up which 290 usually leads to dehydration and death. Secondary bacterial contamination with anaerobes and 291 other bacteria is common (Fig. 6) (Miller et al., 1985, Santurio et al 1998, Perez et al. 2005).

292 It has been suggested that in tropical countries the disease in cattle termed "infectious 293 pododermatitis" usually attributed to anaerobic bacteria, maybe caused by $P$. insidiosum, 294 which could open the door for anaerobic bacteria causing pododermatitis as a secondary 295 infection (Perez et al., 2005).

296 Sheep

297 Pythiosis in sheep has been reported to cause cutaneous lesions in different anatomical areas 298 and as a rhinopharyngeal disease (Tabosa et al. 2004; Riet-Correa et al., 2008). Eosinophilic 299 granulomatous lesions are usually reported on the limbs and rhinopharingeal areas. Clinical 300 signs involving the rhinopharinge include bilateral serosanguineous nasal discharge, swelling 301 of nostrils, and the skin of the face (Fig. 7) (Riet-Correa et al., 2008). Involvement of the 302 lungs has also been reported (Tabosa et al., 2004).

\section{Birds}

304 Only a single report on $P$. insidiosum affecting birds has been recorded (Pesavento et al., 305 2008). The infected animal was a Californian nestling white-faced ibis (Plegadis chihi) with 306 multiple ulceration of its wings, neck, head and limbs. $P$. insidiosum hyphae were found at the 307 centre of necrotizing eosinophilic granulomas. This report shows that $P$. insidiosum can also 308 affect birds and thus veterinarians dealing with birds should investigate similar skin lesions 309 for the presence of this oomycete.

\section{Captive animals}


311 In the last 10 years various reports on pythiosis in captive zoo animals have appeared. The

312 animals involved include animals such as bears, camels and members of the Pantherae such as

313 a tiger and a jaguar. Reports on the following species are available.

\section{Spectacled Bears}

315 How often the disease occurred in this species or the number of cases has yet to be officially

316 reported. So far all cases have come from a zoo in Columbia, South Carolina. Several adult

317 spectacled bears (Tremarctos oronatus) were seen with lesions involving the preputial glands,

318 other cutaneous areas and the gastrointestinal tract (A.A. Padhye, personal communication).

319 The disease has been reported at least twice in this species from the same zoo. The presence

320 of $P$. insidosum in the affected tissue was confirmed by microscopy and culture.

$321 \quad$ Camels

322 Only a single case of pythiosis involving a 4.5 years-old male captive dromedary camel

323 (Camelus dromedarious) in a Florida zoo has been recorded (Wellehan et al., 2004). The

324 animal developed a granulomatous mass on the right side of the face and the diagnosis

325 pythiosis was confirmed by culture. Despite immunotherapy and iodine treatment the camel

326 died six months after the initial diagnosis. At necropsy hyphae of $P$. insidiosum were also

327 found in the third compartment of the stomach. Two unpublished cases of pythiosis in camels

328 from a zoo in Tennessee were recently confirmed (Videla, R. and Mendoza, L. unpublished).

\section{Big cats}

$330 P$. insidiosum has been reported causing an unusual primary pulmonary infection in a seven

331 months old Central American jaguar (Panthera onca) that later died of the infection (Camus

332 et al., 2004). In addition, an adult captive Bengal tiger (Panthera tigris tigris) was diagnosed

333 with abdominal pythiosis in Florida (Buergelt et al. 2006). The tiger later died of the

334 infection. At necropsy several intestinal tumor-like masses were found. The diagnosis was

335 confirmed by serology.

\section{Pythiosis in Humans}

Although it has long been observed in animals, the disease in humans was only

339 recently described in Thai patients (Thianprasit, 1986, 1990). In humans too, pythiosis affects

340 apparently healthy individuals. Susceptible hosts become infected after contact with

341 zoospores through contact of a skin wound with contaminated water. Agricultural related

342 activities or water associated leisure activities are considered to be predisposing factors for

343 human pythiosis (Sathapatayayongs et al., 1989, De Moraes Gimenes Bosco et al., 2005,

344 Supabandhhu J., 2008). Thalassemia is also considered to be a predisposing factor in Thailand 
345 (Sathapatayayongs et al., 1989), but in a population with a high incidence of Thalassemic

346 patients this claim has been questioned (Mendoza et al., 2003b). The majority of human cases

347 (80\%) of pythiosis have been reported in Thailand (Sathapatayayongs et al., 1989,

348 Thianprasit, 1990, Imwidthaya, 1994, Vanittakanakom et al., 2004). Other countries where

349 human pythiosis cases have been reported include: Australia, Brazil, Haiti, Malaysia, New

350 Zealand, and the USA, (Rinaldi, et al., 1989, Triscot et al., 1993, Virgile et al., 1993,

351 Badenoch, et al., 2001, de Moraes Gimenes Bosco et al., 2005). In a report on more than 100

352 cases of pythiosis in Thailand, four different forms of pythiosis were described: a) the (sub)

353 cutaneous form (infecting the face or limbs as a granulomatous and ulcerating lesion), found

354 in $5 \%$ of the cases, b) the vascular type (affecting arteries and resulting in arterial occlusion

355 and aneurysm), found in 59\% of the cases, c) the ocular and orbital form in which corneal

356 ulcers are formed, is found in $33 \%$ of the cases and d) pythiosis at unusual places (i.e.

357 disseminated pythiosis and infection of internal organs, observed in $3 \%$ of the cases

358 (Krajaejun et al., 2006). From a Brazilian study, in which the morphological and molecular

359 characteristics of a new equine isolate were compared with a human isolate, it was clear that

360 both isolates are 99\% similar (De Moraes Gimenes Bosco et al., 2008). The isolates were

361 obtained from the same region. This indicates that both humans and animals are sensitive for

362 the same agent and host specificity of different genotypes seems not very likely. Since all

363 American $P$. insidiosum isolates are included in a single phylogenetic taxon indicating their

364 similarity (Schurko et. al., 2003b), this observation was not unexpected. In the USA human

365 cases of pythiosis are seldom reported and only a small number of cases have been officially

366 published (Rinaldi et al., 1989, Shenep at al., 1998). However, it is likely that pythiosis in the

367 past has been misdiagnosed as a fungal infection (Mendoza et al., 2003). In Australia and the

368 USA children seem more susceptible to the orbicular form (Rinaldi et al., 1989, Triscott et al.,

369 1993, Shenep et al., 1998, Mendoza et al., 2003b), whereas adults develop the subcutanous

370 form.

372 Experimental pythiosis

373 Rabbits

374 The susceptibility of rabbits to experimental infection with $P$. insidiosum was

375 demonstrated almost 100 year ago by Witkamp $(1924,1925)$ and has been used ever since as

376 an experimental model to test the effectiveness of immunotherapy and antimycotic agents

377 (Amemiya, 1969, Ichitani and Amemiya, 1980, Miller and Campbell, 1983, Patino-Meza,

378 1988, Santurio et al., 2003a, Pereira et al., 2007, 2008). It is believed that 17,500 zoospores 
are needed to generate the disease in rabbits (Santurio et al., 2003a). However, Patino-Meza (1988) induced the infection using only 500 or less zoospores. The inoculation with $P$. insidiosum in any other species has been consistently unsuccessful. Patino-Meza (1988) reported no results on the experimental inoculation of $P$. insidiosum in species such as cattle, dogs, and horses. The author used a container with water containing hundreds of $P$. insidiosum zoospores and submerged a horse limb with small skin wounds, without success. Witkamp (1924) mentions that in guinea pigs a similar syndrome as in rabbits develops after experimental infection, but the guinea pigs apparently were suffering much less and their general health was much better. Oddly, natural infection of rabbits with $P$. insidiosum has yet to be documented (Mendoza 2005). In a bizarre report, inoculation of native people and equines with kunkers (from horses with pythiosis) without developing the disease was mentioned (Smith 1884). In summary, experimental pythiosis is only possible in rabbits.

\section{Immunology of Pythium insidiosum infections}

In an early report by veterinarians on equine pythiosis in Indonesia (the former Netherlands India) it was mentioned that infected animals develop anti- $P$. insidiosum antibodies easily detected using antigens extracted from the pathogen in an immunodifussion test (Witkamp, 1924). This was confirmed by serological studies in humans and animals suffering from pythiosis, showing that $P$. insidiosum antigens trigger a humoral immune response upon contact with the host (Miller and Campbell, 1982, Mendoza et al., 1986, Imwidthaya and Srimuang, 1989, Mendoza et al., 1992a, Grooters et al., 2002a, Mendoza and Newton, 2005). It seems, however, that the presence of this type of immunity does, not clear infections in humans or animals (Miller and Campbell, 1982, Mendoza and Alfaro, 1986, Triscott et al., 1993, Thitithanyanont et al., 1998). The cellular immunity, provided by activated macrophages, mast cells, eosinophils and other inflammatory cells, seems directly involved in the extensive tissue damage observed in infected hosts (Miller and Campbell, 1982, Mendoza and Alfaro, 1986). Degranulation of eosinophils and mast cells at the infected sites causes the intensive pruritus reported in horses and other species; and is also responsible for the bacterial contamination occurring after development of necrosis and ulcerating tissue with the classical strong odour reported in equine pythiosis of the skin (Bubberman, 1914).

Based on these data it was postulated that the humoral immunity observed in infected hosts with pythiosis only triggers precipiting and agglutining anti- $P$. insidiosum antibodies related to a T helper 2 (Th2) immune response (Mendoza et al., 2003a, Mendoza and Newton, 2005). These antibodies are not protective, but can be used for the diagnosis of the disease. It 
was further postulated that the cellular immunity triggered by $P$. insidiosum locks the immune system in a Th2 mode which contributes to a worsening of the condition and eventually leads to death. It was suggested that treatment of the disease, using antigenic proteins extracted from $P$. insidiosum (see Immunotherapy below), might nevertheless work if these immunogens were presented to the immune system in a different fashion. The observation that high levels of interferon gamma (IFN- $\gamma$ ) and Interleukin 2 (IL2) (indicators of a Th1 mediated immunity) and a decrease of Th2 mediated interleukins are present in cured patients supports this idea (Thitianyanont et al., 1998, Mendoza and Newton, 2005).

Of interest with respect to the immunology of pythiosis is a report that anti- $P$. insidiosum antibodies developed by different host species seem to detect different $P$. insidiosum antigens. Antibodies present in cattle, horses and humans with pythiosis were seen to bind to different hyphal cell compartments upon immuno-electron microscopy and proteinA colloidal gold -labeling (Garcia et al. (2007). This suggested that different hosts recognize different $P$. insidiosum antigens, which can have implications for the variable response to immunotherapy in some species (see Immunotherapy below). Western blot analysis with sera from bovine, feline, canine, equine and human patients, also showed the detection of different antigens depending on the serum of the species tested (Chindamporn et al., 2009).

Recognition of different dominant $P$. insidiosum antigens by antibodies present in cattle sera, but not by horse and rabbit antibodies has likewise been reported (Leal et al., 2005).

\section{Diagnostics}

Equine pythiosis should not be mistaken for habronemiasis (also named swamp cancer, a disease of horses caused by the nematodes Habronema muscae, H. majus ( $H$. microstoma and Draschia megastoma), skin fungal infections caused by Conidiobolus and Basidiobolus spp., extreme granulation tissue, bacterial granulation tissue or an invasive squamous cell carcinoma (Miller, 1983). Early diagnosis of pythiosis is very important for a successful therapy. Clinical expertise of a veterinarian or physician with the various clinical forms of the disease in different species is crucial for an early diagnosis.

\section{Sample Collection}

For equine pythiosis the collection of several kunkers and their transportation to the laboratory in water or a saline solution with antibiotics (streptomycin and ampicillin) is recommended. Biopts and scrapings should be transported to a laboratory as soon as possible.

The samples have to be washed with distilled water and transported at room temperature in water or saline solution. For long trips (two days or more) the clinical samples (including 
kunkers) should be transported in saline solution with a few drops of broad spectrum antibiotics such as chloramphenicol or tetracycline. However, it was shown that specimens can also be refrigerated and $P$. insidiosum can be recovered from specimens that have been refrigerated for up to 5 days (Grooters et al., 2002b). In our experience however, cooling at $4^{\circ} \mathrm{C}$ (shipping on ice) inhibits growth of $P$. insidiosum from about $20 \%$ of the clinical samples.

A positive diagnosis for $P$. insidiosum infection can be obtained in three ways: a) determination of the presence of the agent by wet mount examination in $10 \% \mathrm{KOH}$ followed by culturing, b) detection of anti-P. insidiosum antibodies using serological assays, and c) detection of DNA of the infectious agent in the infected tissue by PCR and sequencing. Cytology and histology, may help in the diagnosis of pythiosis, but do not allow differentiation between pythiosis and infections caused by the zygomycetes Connidiobolus and Basidiobolus (Miller, 1983, Mendoza, 2005, Grooters, 2007).

\section{a) Culturing and Wet Mount Examination}

Wet mount examination in $10 \% \mathrm{KOH}$ can be performed directly on samples taken from the infected individual. Wet mount preparations are a rapid way to microscopically detect the presence of sparsely septate hyphae, which may suggest the presence of $P$. insidiosum and pythiosis (Fig. 8). Next, a positive diagnosis can be made by culturing followed by sporulation of the pathogen in liquid cultures (Mendoza and Prendas, 1986, Chaiprasert et al., 1990). The production of zoospores alone is not sufficient for a positive diagnosis as other oomycetes produce similar zoospores. Kunkers collected from horses are more likely than biopsied tissues to yield a positive culture. Care should be taken to avoid bacterial contamination upon culturing by the addition of antibiotics and careful processing of samples (Grooters, 2007). Usually, the collected biopsy samples, kunkers (horses) or tissue, are washed three times with sterile saline solution before culture. The tissue is then cut into 5 to $10 \mathrm{~mm}$ in diameter blocks, implanted into $2 \%$ dextrose Sabouraud agar plates and incubated at $37^{\circ} \mathrm{C}$. A beaker with distilled water to increase the humidity inside the incubator is recommended. Positive samples are detected after 24 to 48 hours of incubation as small radiate growing colonies coming from the inoculated blocks (L. Mendoza, unpublished data) (Fig. 1A).

For an accurate diagnosis, a tissue biopsy or tissue deep scrapings can be taken from cutaneous and subcutaneous pythiosis cases; clinical samples can be cultured and microscopically examined for the presence of sparsely septate hyaline hyphae (Fig. 1B). Due to the fact that $P$. insidiosum in culture does not develop sporangia on the commonly used 
481

482

483

484

485

486

487

488

489

490

491

492

493

494

495

496

497

498

499

500

501

502

503

504

505

506

507

508

509

510

511

512

513

514

agar media, the induction of a sporangium producing motile biflagellate zoospores should usually be performed in order to identify the pathogen as $P$. insidiosum (Mendoza and Prendas, 1988, Grooters et al., 2002b) (Fig. 9). All Pythium species develop zoospores in wet cultures in the presence of calcium and magnesium iones. Since $P$. insidiosum was recognized as the only oomycete pathogenic for mammals for a long time, induction of zoosporogenesis was considered enough for a presumptive diagnosis of pythiosis. With the description of an emerging oomycosis in 2003, that still awaits confirmation this might no longer be the case (Grooters et al., 2003). However, further identification of the culture as P. insidiosum by serology or using molecular tools, including sequencing is recommended in any case (Schurko et al., 2004, Mendoza, 2005).

\section{Histopathology}

In contrast to zygomycetes in the order of the mucorales (Absidia, Mucor, Rhizopus, Saksenaea, and others) and in the order of the entomophthorales (Basidiobolus and Conidiobolus) Pythium insidiosum hyphae do not stain well in Hematoxylin and Eosin (H\&E) (Ribes et al., 2000, Mendoza, 2005). Histopathologically a pyrogranulomatous inflammatory infiltration with large quantities of eosinophilic granulocytes is often seen (Rees, 2004, Mendoza, 2005, Grooters, 2007). Although the visualization of hyphae is difficult in H\&E staining, the presence of necrotic eosinophilic granulomas should lead to consideration of the presence of entomophthoromycetous fungi (Conidiobolus and Basidiobolus species), $P$. insidiosum, and/or putative parasitic infections such as habronemiasis in horses (Fig. 10). To visualize $P$. insidiosum hyphae in tissue, samples can be stained with PAS (periodic acidSchiff) or Gomori methenamine silver staining of which the latter is to be preferred (Mendoza, 2005). P. insidiosum hyphae are present as 2.6 to $6.4 \mu \mathrm{m}$ wide (sometimes as large as $>10.0 \mu \mathrm{m}$ ), irregular sparsely septate hyaline filaments with a thick cell wall. Occasionally branches are formed at angles of $90^{\circ}$ degrees (Miller, 1983, Miller and Campbell, 1984, Mendoza and Alfaro, 1986, Mendoza, 2005) (Fig.10).

b) Serodiagnosis.

Serodiagnosis of pythiosis can be performed by immunodiffusion. The test is very specific but unfortunately has a low sensitivity (Mendoza et al., 1986, Prachartam et al., 1991). Other tests based on detection of antibodies, like an Enzyme Linked Immuno-Sorbent Assay (ELISA), an immunochromatographic assay or a Western blot were developed later to increase sensitivity and specificity (Mendoza et al., 1992a, Mendoza et al., 1997, Grooters et al., 2002a,

,Krajaejun et al., 2002, Chindamporn et al., 2009, Krajaejun et al., 2009). Because these tests are difficult to perform in rural areas, Jindayok et al., (2009) developed a haemagglutination 
test in which agglutination of sheep red blood cells coated with a $P$. insidiosum extract is tested against serum samples of patients suspected of pythiosis. The test was found to be simple, rapid and reliable for serodiagnosis of vascular and cutaneous pythiosis. $P$. insidiosum can also be identified in fixed tissues by immunofluorescence (Mendoza et al., 1987) or by the immunoperoxidase staining technique (Brown and Roberts,1988).

c) Molecular diagnosis, PCR. Molecular techniques have been developed to identify P. insidosum in the clinical laboratory in the absence of culture. A specific diagnostic PCR using the internal transcribed spacer (ITS) of the rRNA locus of P.insidiosum has been used by several laboratories (Grooters and Gee, 2002, Reis et al., 2003, Vanittanakom, et al., 2004, de Moraes Gimenes Bosco et al., 2008). Since most skin and intestinal lesions are contaminated with environmental microbes of which DNA sequences are not yet available from the data base, diagnostics based solely on the specific molecular weight of amplicons has to be interpreted with caution. A species specific DNA probe, based on a $530 \mathrm{bp}$ fragment of the ribosomal intergenic spacer (IGS), was developed by Schurko et al. (2004). Although these methodologies are not yet available on a large scale, they can be of help in cases of where fixed tissue is submitted for histopathology (see also serodiagnosis).

\section{Management of pythiosis}

The infections caused by $P$. insidiosum poorly respond to therapy. In addition to wide surgical excision, antimicrobial agents and immunotherapy have been used with some success in the treatment of pythiosis. Independent of the chosen therapy, it is of utmost importance that treatment starts as early as possible.

Radical surgery, including amputation, still is the most used and effective treatment for this infection in humans and animals (McMullan et al., 1977, Mendoza and Alfaro, 1986, Thomas and Lewis, 1998, Krajaejun et al., 2006). Surgical debridement of skin lesions in

541 dogs and horses with the disease is very popular as well but a high rate of reoccurrence is seen 542 (45\%). Some investigators have recommended immunotherapy as an important alternative for 543 the treatment of equine pythiosis.It has to be taken into account that the reported cure rates of 544 different therapies most often are calculated from a small number of patients and that therapy

545 is often a combination of actions like surgical therapy, immunotherapy or administration of 546 antimycotic agents.

\section{$547 \quad$ Antimycotic agents}


Since $P$. insidiosum was believed to be a fungus several antimycotic agents were used to treat the infection (McMullan et al., 1977). However, Stramenopilan microbes such as $P$. insidiosum lack ergosterol in their cytoplasmic membrane and thus should not be susceptible to antimycotic agents (Sekhon et al., 1992, Mendoza, 2005, Mendoza and Newton, 2005). Agents interfering with ergosterol biosynthesis like the azoles (itraconazole, ketoconazole, miconazole, fluconazole etc.) and terbinafine and amphotericin B change the permeability of the cell membrane, causing fungal cell lysis and thus can be expected to have little effect on $P$. insidiosum. Despite this drawback there are reports of clinical success using these drugs (Bissonnette et al., 1991, Triscott et al., 1993, Shenep et al., 1998, Grooters, 2003,). Several reports on the sensitivity of $P$. insidiosum for combinations of ergosterol biosynthesis inhibitors and caspofungin (an inhibitor of $\beta$-glucan synthesis, (Deresinski and Stevens, 2003) have appeared recently (Grooters, 2003, Pereira et al., 2007, 2008, Argenta et al., 2008, Brown et al., 2008, Cavalheiro et al., 2009a, 2009b, Argenta et al., 2010). The oomycete cell wall mainly contains cellulose and $\beta$-glucan, which is an essential component of the cell wall (Hendrix, J.W., 1964). Consequently, in these reports inhibitors of $\beta$-glucan synthesis (like caspofungin) have been tested.

Caspofungin when tested in vivo in a model such as the rabbit, generates a reduction in the growth of the lesions in treated animals. Growth of the lesions resumes when therapy is stopped (Pereira et al., 2007). Combinations of terbinafine and itraconazole or voriconazole performed better against a number of isolates of $P$. insidiosum than each agent apart (Argenta et al., 2008). An observation also made for combinations of terbinafine and amphotericin B, metronidazole, rifampicin, ibuprofen and fluvastatin (Carvalheiro et al., 2009a, 2009b). It is of concern that a high variability in susceptibility of the different $P$. insidiosum strains used in these studies was observed (Cavalheiro et al., 2009a). An antimycotic agent that awaits further study of its usefulness against $P$. insidiosum infection is the phenylamide compound mefenoxam, an inhibitor of RNA polymerase that has been used against plant pathogenic oomycetes (Brown et al., 2008). Unfortunately, the extensive testing of new antimycotic drugs in animals is often hampered by the costs involved. Immunotherapy

Immunotherapy for the treatment of pythiosis in horses has been used for more than 20 years and more than 600 animals have been treated today (Miller, 1981, Mendoza and Alfaro, 1986, Mendoza and Newton, 2005). The first vaccine, developed in 1981 and derived from killed ultrasonicated mycelium, was effective in half of the equine patients and clinical 
antigens secreted by P.insidiosum and obtained from a broth culture after precipitation was tested in a number of horses from Costa Rica (Mendoza and Alfaro, 1986). The efficacy of this vaccine was not much different from the efficacy of the vaccine developed by Miller, but it is more stable and easier to prepare (Mendoza et al., 2003). In a clinical study involving 18 infected horses and 6 infected dogs which were treated with $P$. insidiosum-vaccine $72 \%$ of the horses and 2 dogs were cured. It is important to note that the cure rates in this study were obtained by combination therapies using either surgery or antimycotical agents. Most animals that were treated developed a mild reaction at the injection site (Mendoza and Newton, 2005). After a week of immunotherapy it became evident that the hyphae of $P$. insidiosum in the infected tissue were damaged. In dogs this therapy was also applied with some success (Hensel et al., 2003). Immunotherapy in dogs has a lower cure rate than in horses and in cats it has only has been tested three times with no response whatsoever (Thomas and Lewis, 1998). In cattle immunotherapy worked in the majority of the treated cases, about 65 animals have been treated with success. This variation in success rate between species is intriguing and deserves further study (see also Immunology of Pythium insidiosum infections). Vaccines prepared from extracts of $P$. insidiosum cultures in liquid medium with ultrasound or by vortexing have also been used for immunotherapy. The vaccine prepared by ultrasound treatment showed no effect on the lesions while the vortexed vaccine reduced the lesions in experimental rabbits by $71 \%$ (Santurio et al., 2003a).

In humans, immunotherapy was first successfully used in 1998 in a Thai boy who had a $P$. insidiosum vascular infection where surgery and antimycotic therapy did not work adequately. The boy was given a dose of $P$. insidiosum vaccine twice, with an interval of 2 weeks and within a year healing occurred (Thitithanyanont et al., 1998). In a clinical study in people suffering from the vascular form of pythiosis, immunotherapy was used as a last resort (Wanachiwanawin et al., 2004). After two administrations of the vaccine with a two week interval, four patients reacted positively to the vaccine, two patients moderately and two patients showed no response. The last two deceased within a short time. It is assumed that the success of this therapy is better if it is applied as soon as the disease is diagnosed. The mortality increases especially when people suffer from chronic lesions older than two months (Wanachiwanawin et al., 2004). Until now $\sim 60$ Thai patients have been treated with immunotherapy against $P$. insidiosum infection with about $55 \%$ cure rate.

A likely explanation for the mechanism by which immunotherapy against P.insidiosum infection works is that a switch in the host's immune response occurs from a Th2 (during infection) to a Th1 immune response (after immunotherapy) (Mendoza et al., 
2003, Mendoza and Newton, 2005). This is supported by the detection of an increase in interleukins related to Th1 or Th2 immune responses (Thitithanyanont et al., 1998). For instance, the immune response to $P$. insidiosum infection in humans appears in all cases to be characterized by an elevated response in interleukin 4 and 5 production, with high IgE titers, and inflammatory cells such as mast cells and eosinophils present in large amounts. This response is consistent with a Th2 response and suggests that the pathogen has developed an evolutionary strategy to present antigens to the immune system that may trigger such a response. In contrast, in vaccinated cured patients a response with high titres of interleukin 2 and INF- $\gamma$ which induce a mononuclear immune response, typical of a Th1 response is triggered (Thitithanyanont et al., 1998, Mendoza et al., 2003a). Details of the immune response triggered during infection and after immunotherapy are shown in (Fig. 11). It has been argued that an effective treatment of $P$. insidiosum in the future should include immunotherapy and a combination of both immunotherapy and surgery or immunotherapy and antifungal drugs (Mendoza and Newton, 2005). A rapid diagnosis and an early start of the treatment are essential in the management of this infection (Mendoza and Newton, 2005).

\section{Prevention}

$P$. insidiosum infection occurs after exposure of hosts with an open skin to environments containing propagules (zoospores or hyphae) of the pathogen. Tropical wetland environments have been implicated as important infection sites including ponds of water, soil and grass in the endemic areas. People and animals in contact with zoospores (incriminated as the infecting units) from the environment are at risk of contracting the infection. Besides zoospores, hyphae and resting oospores are also seen as a possible source of infection. Acquiring the infection from infected animals has not yet been reported (Mendoza, 2005, Mendoza and Newton, 2005). In fact, Arvis (1916) mentions explicitly that a foal touching an infected area beside the udder with its nose and lips for weeks stayed completely healthy. Nevertheless, physicians and medical personnel should handle cases of the disease carefully wearing protective gloves during treatment of wounds in humans and animals suffering from pythiosis.

\section{Conclusions}

Pythium insidiosum is the cause of pythiosis, a rare non-transmissible disease that currently occurs in the tropics, subtropics and some temperate regions. However, in view of the global warming it can be expected that this disease could spread to more temperate areas 
650 in the world (Mendoza, 2009). Relatively few cases of pythiosis are reported yearly,

651 irrespective of the species infected, but this is very likely an underestimation as the disease

652 mainly occurs in rural areas in developing countries. Pythium insidiosum has the appearance

653 of a fungus, but is closely related to algae and diatomaea. Infection occurs mainly in horses,

654 dogs and humans. Infections are caused by motile zoospores that are present in surface water

655 and infect an apparently healthy individual through small skin lesions. The zoospores are

656 attracted to these wounds or lesions by a chemo-attractant. No individual-individual

657 transmission occurs. Extensive surgery is in many cases the only way to treat patients. This is

658 not always successful and death of patients occurs regularly. Immunotherapy is also relatively

659 successful but a marked difference in response to immunotherapy from one species to another

660 is observed. The meaning of the immunogenic preferences within different hosts is not

661 known, but ongoing investigations in this area hopefully will soon shed some light on this

662 peculiar finding.

663 Since $P$. insidiosum is not a true fungus it does not react well to treatment with

664 antifungal agents. The search for a chemical therapy for this disease therefore has to continue

665 unabated. Little is known about potential virulence factors of the agent. Hopefully knowledge

666 of this aspect of $P$. insidiosum pathogenesis will increase once the complete nucleotide

667 sequence of its genome becomes available. In general the molecular biology of P.insidiosum

668 pathogenesis is not yet well developed in comparison to other infectious agents. Until then, $P$.

669 insidiosum will remain a fascinating microbe for those who study it and a devastating one for

670 those who suffer from it.

671

672 Acknowlegements.

673 We would like to thank Dr. Y. Perazzo, Dr. R.C. Thomas,, Dr. R. C. Perez, Dr. J.J. Luis-

674 Leon, Dr. F. Riet-Correa and Dr. S.M.S. Silva for allowing us to use the pictures shown in

675 Figs. 4, 5, 6 and 7.

676

677 Conflict of interest.

678 A conflict of interest of one of the authors (LM) concerning immunotherapy should be reported. The author has a commercial interest in the immunotherapy product.

\section{References}


Alfaro, A.A., Mendoza, L., 1990. Four cases of equine bone lesions caused by Pythium insidiosum. Equine Vet. J. 22, 295-297.

Allison, N., Gillis, J.P., 1990, Enteric pythiosis in a horse. J. Am. Vet. Med. Assoc. 196, 462-464.

Amemiya, J., 1969. Isolation of a fungus of the Mortierellaceae from an equine granular dermatitis III. Bull. Fac. Agric. Kagoshima Univ. 19, 31-50.

Amemiya, J., 1982. Granular dermatitis in the horse, caused by Pythium gracile. Bull Fac Agric Kagoshima Univ., 32, 141-147.

Argenta, J.S., Santurio, J.M., Alves, S.H., Pereira, D.I., Cavalheiro, A.S., Spanamberg, A., Ferreiro, L., 2008. In vitro activities of voriconazole, itraconazole, terbinafine, alone or in combination against Pythium insidiosum isolates from Brazil. Antimicrob. Agents Chemother. 52, 767-769.

Argenta, J.S., Alves, S.H., Silveira, F., Maboni, G., Pereira, D.I.B., Spanamberg, A., Santurio, J.M., Ferreiro, L., 2010. In vitro paradoxical growth of Pythium insidiosum in the presence of caspofungin. Vet. Microbiol., doi10.1016/j.vetmic.2010.04.001.

Austwick, P.K.C., Copland, J.W., 1974. Swamp cancer. Nature 250, 84.

Avis, J.A.R., 1916. Hyphomycosis destruens equi. Veeartsenijkundige Bld. voor Ned. Indë 28, 34-38.

Badenoch, P.R., Coster, D.J., Wetherall, B.L., Brettig, H.T., Rozenbilds, M.A., Drenth, A., Wagels G., 2001. Pythium insidiosum keratitis confirmed by DNA sequence analysis. Br. J. Ophthalmol. 85, 502-503.

Bangyeekhun, E., Cerenius, L., Sőderhäll, K., 2001, Molecular cloning and characterization of two serine proteinase genes from the crayfish plague fungus, Aphanomyces astaci. J. Invertebr. Pathol. 77, 206-216.

Berryessa, N.A., Marks, S.L., Pesavento, P.A., Krasnansky, T., Yoshimoto, S.K., Johnston, E.G., Grooters, A.M., 2008 Gastrointestinal Pythiosis in 10 Dogs from California. J. Vet. Intern. Med. 22, 1065-1069.

Bissonnette, K.W., Sharp, N.J., Dykstra, M.H., Robertson, I.R., Davis, B., Padhye, A.A. Kaufman, L., 1991. Nasal and retrobulbar mass in a cat caused by Pythium insidiosum. J. VMed. Vet. Mycol. 29, 39-44.

Bridges, C. H., Emmons, C.W., 1961. A phycomycosis of horses caused by Hyphomyces destruens. J. Am. Vet. Med. Assoc. 138, 579-589.

Brown, C.C., Roberts, E.D., 1988. Intestinal pythiosis in a horse. Aust. Vet. J. 65, 88-89.

Brown, T.A., Grooters, A.M., Hosgood, G.L., 2008. In vitro susceptibility of Pythium insidiosum and a Lagenidium sp to itraconazole, posaconazole, voriconazole, terbinafine, caspofungin, and mefenoxam. Am. J. Vet. Res. 69, 1463-1468.

Bubberman, C., 1914. Twee uitgebreide gevallen van Hyphomycosis destruens equi. Veeartsenijkundige Mededeeling 12, 2-17.

Buergelt, C., Powe, J., White, T., 2006. Abdominal pythiosis in a Bengal tiger (Panthera tigris tigris). J. Zoo Wildl. Med. 37, 186-189.

Camus, A.C., Grooters, A.M., Aquilar, R.F., 2004. Granulomatous pneumonia caused by Pythium insidiosum in a central American jaguar, Panthera onca. J. Vet. Diagn. Invest. 16, 567-571.

Cavalheiro, A.S., Mabon, G., de Azevedo, M.I., Argenta, J.S., Pereira, D.I.B., Spader, T.B., Alves, S.H., Santurio, J.M., 2009a. In vitro activity of terbinafine combined with caspofungin and azoles against Pythium insidiosum. Antimicrob. Agents Chemother. 53, 2136-2138.

Cavalheiro, A.S., Zanette, R.A., Spader, T.B., Lovato, L., Azevedo, M.I., Botton, S., Alves, S.H., Santurio, J.M., 2009b. In vitro activity of terbinafine associated to amphotericin B, fluvastatin, rifampicin, metronidazole and ibuprofen against Pythium insidiosum. Vet. Microbiol. 137, 408-411.

Chaffin, M.K., Schumacher, J., McMullan, W.J., 1995. Cutaneous pythiosis in the horse. Vet Clin North Am: Equine Pract. 11, 91-103.

Chaiprasert, A., Samerpitak, S., Wanachiwanawin, W., Thasnakorn, P., 1990. Induction of zoospore formation in Thai isolates of Pythium insidiosum. Mycoses 33, 317-323.

Chandler, F. W., W. Kaplan, W., Ajello, L., 1980. A color atlas and textbook of the histopathology of mycotic diseases,. Year Book Medical Publishers, Inc., Chicago pp. 104-105.

Chindamporn, A., Vilela, R., Hoag, K.A., Mendoza, L., 2009. Antibodies in the sera of host species with Pythiosis recognize a variety of unique immunogens in geographically divergent Pythium insidiosum strains. Clin. Vac. Immunol. 16, 330-336.

Davis, D.J., Lanter, K., Makselan, S., Bonati, C., Asbrock, P., Ravishankar, J.P., Money, N.P., 2006. Relationship between temperature optima and secreted protease activities of three Pythium species and pathogenicity toward plant and animal hosts. Mycol. Res. 110, 96-103.

De Cock, A.W., Mendoza, L., Padhye, A., Ajello, L., Kaufman, L., 1987. Pythium insidiosum sp. Nov., the etiologic agent of pythiosis. J. Clin. Microbiol. 25, 344-349.

De Haan, J., Hoogkamer, L.J., 1901. Hypho-mycosis destruens. Veeartsennijkundige. Bld. voor Ned. Indië 13, 350-374.

De Haan, J., 1902. Bosartige Schimmelkrankheit des Pferdes (Hyphomycosis destruens equi). Zentralbl. Bakt. Parasitenkd. Infektionskr. Hyg. Abt. 1 Orig. 31, 758-763. 
De Moraes Gimenes Bosco, S., Bagagli, E., Araújo, J.P. Jr., Candeias, J.M., de Franco, M.F., Alencar Marques, M.E., Mendoza, L., de Camargo, R.P., Alencar Marques, S., 2005. Human pythiosis, Brazil. Emerg Infect Dis. 11, 715-718.

De Moraes Gimenes Bosco, S., Martins Reis, G., Cordeira Theodora, R., Assis da Graça Macoris, S., Alencar Marques, S., Da Graça Macoris, D., Bagagli, E., 2008. Morphological and molecular characterization of an equine isolate of Pythium insidiosum and comparison with the first human isolate from the same geographic region. Med. Mycol. 46, 557-565.

Deresinski, S.C., Stevens, D.A., 2003. Caspofungin. Clin. Infect. Dis., 36, 1445-1457.

Dick, M.W., 2001. Straminipilous fungi: systematics of the peronosporomycetes including accounts of the marine straminipilous protist, the plasmodiophorids and similar organisms. Kluwer Academic publishers, London, England. pp.67.

Drouin, V. 1896. Sur une nouvelle mycose du cheval. Recl. Med. Vet. 3, 337-344.

Estrada-Garcia, M.T., Callow, J.A., Green, J.R., 1990. Monoclonal antibodies to the adhesive cell coat secreted by Pythium aphanidermatum zoospores recognize 200x300Mr glycoproteins stored within large peripheral vesicles. J. Cell. Sci. 95, 199-206.

Fish, P.A., 1895-96. Leeches: a histological investigation of two cases of equine mycosis with a historical account of a supposed similar disease,called bursatte, occurring in India. $12^{\text {th }}$ and $13^{\text {th }}$ Annual Report of the Bureau of Animal Industry 229-259.

Fischer, J.R., Pace, L.W., Turk, J.R., Kreeger, J.M., Miller, M.A., Gosser, H.S., 1994. Gastrointestinal pythiosis in Missouri dogs: eleven cases. J. Vet. Diagn. Invest. 6, 380-382.

Garcia, R.B., Pastor, A., Mendoza L., 2007. Mapping of Pythium insidiosum hyphal antigens and ultrastructural features using TEM. Mycol. Res. 111, 1352-60.

Goad, M.E., 1984. Pulmonary pythiosis in a horse. Vet. Pathol. 21, 261-262.

Gonzalez, H.E., Ruiz, A., 1975. Espundia equina: Etiologia y patogenesisi de una ficomicosis. Revista ICA Bogota (Colombia) 10, 175.

Grooters, A.M., 2003. Pythiosis, lagenidosis and zygomycosis in small animals. Vet. Clin. North. Am. Small. Anim. Pract. 33, 695-720.

Grooters, A.M., 2007.Pythiosis and Zygomycosis. In: Sellon, D., Long, M. (Eds), Equine Infectious Diseases. Saunders Elsevier, St. Louis, Missouri, USA, pp. 412-419.

Grooters, A.M., Gee, M.K., 2002. Development of a nested polymerase chain reaction assay for the detection and identification of Pythium insidiosum. J. Vet. Intern. Med. 16, 147-152.

Grooters A.M., Hodgin, E.C., Bauer, R.W., DeTrisac, C.J., Znajda, N.R., Thomas, R.C., 2003. Clinicopathologic findings associated with Lagenidium sp. infection in 6 dogs: initial description of an emerging oomycosis. J Vet Intern Med. 17, 637-46.

Grooters, A.M., Leise, B.S., Lopez, M.K., O’Reilly, K.L., 2002a. Development and evaluation of an Enzyme-Linked Immunosorbent Assay for the serodiagnosis of pythiosis in dogs. J. Vet. Intern. Med. 16, 142146.

Grooters, A.M., Whittington, A., Lopez, M.K., Boroughs, M.N., Roy, A.F., 2002b. Evaluation of microbial culture techniques for the isolation of Pythium insidiosum from equine tissues. J. Vet. Diagn. Invest. 14, 288-294.

Headley, S.A., Arruda, H.N., Leggi, T.C.S.S., Bett, V., 2002. Cutaneous pythiosis in a slaughtered horse: a case report. Arq. Inst. Biol. 69, 109-112.

Hendrix, J.W., 1964. Sterol induction of reproduction and stimulation of growth of Pythium and Phytophtora. Science 144, 1028-1029.

40. Hensel, P., Greene, C.E., Medleau, L., Latimer, K.S., Mendoza, L., 2003. Immunotherapy for treatment of multicentric cutaneous pythiosis in a dog. J. Am. Vet. Med. Assoc. 223, 215-218.

Hudspeth, D.S.S., Nadler, S.A., Hudspeth, M.E.S., 2000. A COX2 molecular phylogeny of the peronosporomycetes. Mycologia 92, 674-684.

Ichitani, T., Amemiya, J., 1980. Pythium gracile isolated from the foci of granular dermatitis in the horse (Equus caballus). Trans Mycol Soc Jpn. 21, 263-265.

Imwidthaya, P., 1994. Human pythiosis in Thailand. Postgraduate Medicine J. 70, 558-560.

Imwidthaya, P., Srimuang, S., 1989. Immunodiffusion test for diagnosing human pythiosis. Mycopathologia, 106, 109-112.

Jindayok, T., Piromsontikorn, S., Srimuang, S., Khupulsup, K., Krajaejun, T., 2009. Hemagglutination test for rapid serodiagnosis of human pythiosis. Clin. Vac. Immunol. 16, 1047-1051. $143,3-7$

Kaufman, L., 1998. Penicillosis marneffei and pythiosis: emerging tropical diseases. Mycopathologia

Kerr, J., 1829. On the disease to which horses are subject to the East Indies, termed baursette. Veterinarian 2, 419-421. 

94, 123-129.

Krajaejun, T., Imkhieo, S., Intaramat, A., Ratanabanangkoon, K., 2009 Development of an immunochromatographic test for rapid serodiagnosis of human pythiosis. Clin. Vac. Immunol. 16, 506-509.

Krajaejun, T., Sathapatayavongs, B., Pracharktam, R., Nitiyanant, P., Leelachaikul, P., Wanachiwanawin, W., Chaiprasert, A., Assanasen, P., Saipeth, M., Mootsikapun, P., Chetchotisakd, P., Lekhakula, A., Mitarnun, W., Kalnauwakul, S., Supparatpinyo, K., Chaiwarith, R., Chiewchanvit, S., Tananuvat, N., Srisri, S., Suankratay, C., Kulwichit, W., Womgsaisuwan, M., Somkaew, S., 2006. Clinical and Epidemiological Analysis of Human Pythiosis in Thailand. Clin. Infect. Dis. 43, 569-576.

Krajaejun, T., Kunakorn, M., Niemhom, S., Chongtrakool, P., Pracharktam, R., 2002. Development and evaluation of an in-house enzyme-linked immunosorbent assay for early diagnosis and monitoring of human pythiosis. Clin. Diagn. Lab. Immunol. 9, 378-82.

Kwon-Chung, K.J., 1994. Phylogenetic spectrum of fungi that are pathogenic to humans. Clin. Infect. Dis. 19, S1-7.

Laohapensang, K., Rutherford, R.B., Supabandhu, J., Vanittanakom, N., 2009. Vascular pythisosis in a thalassemic patient. Vascular 17, 234-238.

Leal, A.B., Leal, A.T., Santurio, J.M., Kommers, G.D., Catto, J.B. 2001. Pitiosis eqüina no Pantanal brasileiro: aspectos clínico-patológicos de casos típicos e atípicos. Pesq.Vet. Bras. 21, 151-56.

Lévesque, C.A., de Cock, A.W., 2004. Molecular phylogeny and taxonomy of the genus Pythium. Mycol. Res. 108, 1363-1383.

- MacDonald, E., Millward, L., Ravishankar, J.P., Money, N.P., 2002. Biomechanical interaction between hyphae of two Pythium species (Oomycota) and host tissues. Fungal Gen. Biol. 37, 245-249.

Martin, F.N., 2000. Phylogenetic relationships among some Pythium species inferred from sequence analysis of the mitochondrially encoded cytochrome oxidase II gene. Mycologia 92, 711-727.

McMullan, W.C., Joyce, J.R., Hanselka, D.V., Heitmann, J.M., 1977. Amphothericin B for the treatment of localized subcutaneous phycomycosis in the horse. J. Am. Vet Med. Assoc. 170:1293-8.

Mendoza, L., 2005. Pythium insidiosum. In: Merz, W.G., Hay, R.J. (eds). Topley and Wilson's Microbiology and Microbial Infections. Medical Mycology 10th edition. pp. 617-30.

Mendoza, L., 2009. Pythium insidiosum and mammalian hosts. In: K. Lamour and S. Kamoun (eds). Oomycete Genetics and Genomics. Diversity, interaction, and research tools.. Wiley-Blackwell pp. 387-405.

Mendoza, L., Ajello, L., McGinnis, M.R., 1996. Infections caused by the oomycetous pathogen Pythium insidiosum. J. Mycol. Med. 6, 151-164.

Mendoza, L., Alfaro, A.A., 1986. Equine pythiosis in Costa Rica:Report of 39 cases. Mycopathologia,

Mendoza, L., Alfaro, A.A., and Villalobos, J. 1988. Bone lesions caused by Pythium insidiosum in a horse. J. Med. Vet. Mycol. 26, 5-12

Mendoza, L., Hernandez, F., Ajello, L., 1993. Life Cycle of the human and animal oomycete pathogen Pythium insidiosum. J. Clin. Microbiol. 31, 2967-2973.

Mendoza, L., Kaufman, L., Mandy, W., Glass, R., 1997. Serodiagnosis of human and animal pythiosis using an enzyme-linked immunosorbent assay. Clin. Diagn. Lab. Immunol. 4, 715-718.

Mendoza, L., Kaufman, L., Standard, P.G., 1986. Immunodiffusion test for diagnosing and monitoring pythiosis in horses. J. Clin. Microbiol. 23, 813-816.

Mendoza, L., Kaufman, L., Standard, P., 1987. Antigenic relationship between the animal and human pathogen Pythium insidiosum and nonpathogenic Pythium spp. J. Clin. Microbiol. 25, 2159-2162.

Mendoza, L., Mandy, W., Glass, R., 2003. An improved Pythium insidiosum-vaccine formulation with enhanced therapeutic properties in immune horses and dogs with pythiosis. Vaccine 21, 2797-2804.

Mendoza, L, Marin, G., 1989. Antigenic relationship between Pythium insidiosum de Cock et al.1987 and its synonym Pythium destruens Shipton 1987. Mycoses 32, 73-77.

Mendoza, L., Newton, J. C., 2005. Immunology and immunotherapy of the infections caused by Pythium insidiosum. Med. Mycol. 43, 477-486.

Mendoza, L., Nicholson, V., Prescott, J.F., 1992a. Immunoblot analysis of the humoral immune response to Pythium insidiosum in horses with pythiosis. J. Clin. Microbiol. 30, 2980-2983.

Mendoza, L., Prasla, S.H., and Ajello. 2003. Orbital pythiosis: a non-fungal disease mimicking orbital mycotic infection, with retrospective review of the literature Mycoses 47, 14-23

Mendoza, L., Prendas, J., 1988. A method to obtain rapid zoosporogenesis of Pythium insidiosum. Mycopathologia 104, 59-62.

Mendoza, L., Villalobos, J., Calleja, C.E., Solis, A., 1992b. Evaluation of two vaccines for the treatment of pythiosis insidiosi in horses. Mycopathologia, 119, 89-95.

Miller, R.I., 1981. Treatment of equine phycomycosis by immunotherapy and surgery. Aust. Vet. J. 57, 377-382.

Miller, R.I., 1983. Granulomatous and neoplastic disease of equine skin. Veterinary Reviews and Monographs No 6. James Cook University of North Queensland, Townsville, Australia. pp 1-92. 
Miller, R.I., Campbell, R.S., 1983. Experimental pythiosis in rabbits. Sabouraudia 21, 331-341.

Miller, R.I., Campbell, R.S., 1984. The comparative pathology of equine cutaneous phycomycosis. Vet. Pathol. 21, 325-332.

Miller, R.I., Olcott, B.M., Archer, M., 1985. Cutaneous pythiosis in beef calves. J. Am. Vet. Med. Assoc. 186, 984-986.

Morton, L.D., Morton, D.G., Baker, G.J., Gelberg, H.B., 1991. Chronic eosinophilic enteritis attributed to Pythium sp. in a horse. Vet. Pathol. 288, 542-544.

Murdoch, D., Parr, D., 1997. Pythium insidiosum keratitis. Australian New Zealand J. of Ophthalmology 25, 177-179.

Patino-Meza, F., 1988. Role of the zoospores of Pythium insidiosum in the experimental reproduction of pythiosis in susceptible species. DVM thesis, National University, Heredia, Costa Rica 1-31.

Pereira, D.I.B., Santurio, J.M., Alves, S.H., Argenta, J.S., Potter, L., Spanamberg, A., Ferreiro, L., 2007 Caspofungin in vitro and in vivo activity against Brazilian Pythium insidiosum strains isolated from animals. J. Antimicrob. Chemother. 60, 1168-1171.

Pereira, D.I.B., Santurio, J.M., Alves, S.H., de Azevedo, M.I., Silveira, F., da Costa, F.F., Sallis, E.S.V., Pötter, L., Ferreiro, L., 2008. Comparison between immunotherapy and caspofungin as agents to treat experimental pythiosis in rabbits. J. Mycol. Med. 18, 129-133.

Pérez, R., Luis-León, J.J., Vivas, J.L., Mendoza, L., 2005. Epizootic cutaneous pythiosis in beef calves. Vet. Microbiol. 109, 121-128.

Pesavento, P.A., Barr, B., Riggs, S.M., Eigenheer, A.L., Pamma, R., Walker, R.L., 2008. Cutaneous pythiosis in a nestling white faced ibis. Vet. Pathol. 45, 538-541.

Pracharktam, R., Changtrakool, P., Sathapatayavongs, B., Jayanetra, P., Ajello, L., 1991. Immunodiffusion test for diagnosis and monitoring of human pythiosis insidiosi. J. Clin. Microbiol., 29, 138141.

Pupaibool, J., Chindamporn, A., Patarakul, K., Suankratay, C., Sinduphak, W., Kulwichit, W., 2006. Human Pythiosis. Emerg. Infect. Dis. 12, 517-518.

Purcell, K.L., Johnson, P.J., Kreeger, J.M., Wilson, D.A., 1994. Jejunal obstruction caused by a Pythium insidiosum granuloma in a mare. J. Am. Vet. Med. Assoc. 205, 337-339.

Rakich, P.M., Grooters, A.M., Tang, K-N., 2005. Gastrointestinal pythiosis in two cats. J Vet. Diagn. Invest. 17,262-269.

Ravishankar, J.P., Davis, C.M., Dacis, D.J., MacDonald, E., Makselan, S.D., Millward, L., Money, N.P., 2001, Mechanics of solid tissue invasion by the mammalian pathogen Pythium insidiosum. Fung. Genet. Biol. 34, 167-175.

Rees, C.A., 2004. Disorders of the skin. In: Reed, S.M., Bayly, W.M., Sellon, D.C., Equine Internal Medicine. Saunders, $2^{\text {nd }}$ edition: 695-696.

Reis, J.L., Quirez de Carvalho, E.C., Girăo Nogueira, R.H., Lemos, L.S., Mendoza, L., 2003.

Disseminated pythiosis in three horses. Vet. Microbiol. 96, 289-295.

Ribes, J.A., Vanover-Sams, C.L., Baker, D.J., 2000. Zygomycetes in human disease. Clin. Microbiol. Rev. 13, 236-301.

Riet-Correa, F., Dantas, A.F.M., Azevedo E.O., Simoes, S.D.V., Silva, S.M.S., Vilela, R., Mendoza, L., 2008. Outbreak of rhinopharyngeal zygomycosis in sheep in Paraiba, Northeastern Brazil. Pesq. Vet. Bras. 28, 29-35.

Rinaldi, M.G., Seidenfeld, S.M., Fotherbill, A.M., McGough, D.A.,1989. Pythium insiidosum causes a severe disease in a healthy boy. Mycol. Observer 9, 7.

Rivierre, C., Laprie, C., Guiard-Marigny, O., Bergeaud, P., Berthelemy, M., Guillott, J., 2005. Pythiosis in Africa. Emerg. Infect. Dis. 11, 479-481.

Santurio, J.M., Argenta, J.A., Schwendler, S.E., Cavalheiro, A.S., Pereira, D.I.B., Zanette, R.A., Alves, S.H., Dutra, V., Silva, M.C., Arruda, L.P., Nakazata, L., Colodel, E.M., 2008. Granulomatous rhinitis associated with Pythium insidiosum infection in sheep. Vet. Rec. 163, 276-277.

Santurio, J.M., Leal, A.T., Leal, A.B.M., Festugatto, R., Lubeck, I., Sallis, E.S.V., Copetti, M.V., Alves, S.H., Ferreiro, L., 2003a. Three types of immune therapy against pythiosis insidiosi developed and evaluated. Vaccine 21, 2535-2540.

Santurio, J.M., Leal, A.T., Monteiro, A.B., 2003b. Pythiose. In: Lefévre, P.C., Blancou, J., Chermette, R., (eds). Principales maladies infectieuses et parasitaires de bétail. Lavoisier, Paris. pp. 1231-1241.

Santurio, J.M., Monteiro, A.B., Leal, A.T., Kommers, G.D., de Sousa, R.S., Catto, J.B., 1998. Cutaneous Pythiosis insidiosi in calves from the Pantanal region of Brazil. Mycopathologia 141, 123-125.

Sathapatayayongs, B., Leelachaikul, P., Prachaktam, R., Atichartakarn, V., Sciphojanart, S., Trairatvorakul, P., Jirasiritham, S., Nontasut, S., Eurvilaichit, C., Flegel, T., 1989. Human pythiosis associated with thalassemia hemoglobinopathy syndrome. J.Infect. Dis. 159, 274-280. 
Schurko, A.M., Mendoza, L., de Cock, A.W., Klassen, G.R., 2003a. Evidence for geographic clusters: molecular genetic differences among strains of Pythium insidiosum from Asia, Australia and the Americas are explored. Mycologia 95, 200-208.

Schurko, A.M., Mendoza, L., Lévesque, C.A., Désaulniers, N.L., de Cock, A.W., Klassen, G.R., 2003b. A molecular phylogeny of Pythium insidiosum. Mycol. Res. 107, 537-544.

Schurko, A.M., Mendoza, L., de Cock, A.W.A.M., Bedard, J.E.J., Klassen, G.R., 2004. Development of a species specific probe for Pythium insidiosum and the diagnosis of Pythiosis. J. Clin. Microbiol. 42, 2411 2418.

Sekhon, A.S., Padhye, A.A., Garg, A.K., 1992. In vitro sensitivity of Penicillum marneffei and Pythium insidiosum to various antifungal agents. Eur. J. Epidemiol. 8, 427-432.

Shenep, J.L., English, B.H., Kaufman, L., Pearson, T.A., Thompson, J.W., Kaufman, R.A., Frisch, G., Rinaldi, M.G., 1998. Successful medial therapy for deeply invasive facial infection due to Pythium insidiosum in a child.Clin. Infect. Dis. 27, 1388-1393.

Shipton, W.A., 1987. Pythium destruens sp.nov., an agent of equine pythiosis. J. Med. Vet. Mycol. 25, 137-151.

Smith, F., 1884. The pathology of bursattee. Vet. J., 19, 16-17.

Sohn, Y., Kim, D., Kweon, O., Seo, I., 1996. Enteric pythiosis in a Jindo dog. Korean J. Vet. Res. 36, 447-51.

Supabandhu, J., Mathew C.F., Mendoza, L., Vanittanakom, N. 2008. Isolation and identification of the human pathogen Pythium insidiosum from environmental samples collected in Thai agricultural areas. Med. Mycol. 46, 41-52.

Tabosa, I.M., Riet-Correa, A.F., Nobre, V.M.T., Azevedo, E.O., Reis-Jũnior, J.L., Medeiros, R.M.T., 2004. Outbreaks of pythiosis in two flocks of sheep in northeastern Brazil. Vet. Pathol. 41, 412-415.

Thianprasit, M. 1986. Fungal infection in Thailand. Jpn J Dermatol. 96, 1343-1345.

Thianprasit, M. 1990. Human pythiosis. Trop Dermatol. 4, 1-4.

Thitithanyanont ,A., Mendoza, L., Chuansumrit, A., Prachartam, R., Laothamatas, J., Sathapatayayongs, B., Lolekha, S., Ajello, L., 1998. Use of an immunogenic therapeutic vaccine to treat a lifethreatening human arteritic infection caused by Pythium insidiosum. Clin. Infect. Dis., 27, 1394-1400.

Thomas, R.C., Lewis, D.T., 1998. Pythiosis in dogs and cats. Compend. Contin. Educ. Pract. Vet. 20, $63-74$.

Torto-Alalibo, T., Tian, M., Gajendran, K., Waugh, M.E., van West, P., Kamoun, S., 2005. Expressed sequence tags from the oomycete fish pathogen Saprolegnia parasitica reveal putative virulence factors. BMC. Microbiol. 5, 46.

Triscott, J.A., Weedom, D., Cabana, E., 1993. Human subcutaneous pythiosis. J. Cutaneous Pathol. 20, 267-271.

Virgile, R., Perry, H.D., Pardanani, B., Szabo, K., Rahn, E.K., Stone, J., Salkin, I., Dixon, D.M., 1993. Human corneal ulcer caused by Pythium insidiosum. Cornea 12, 81-3.

Vanittanakom, N., Supabandhu, J., Khamwan, C., Praparattanapan, J., Thirach, S., Prasetwikayakij, N., Louthrenoo, W., Chiewchanvit, S., Tananuvat, N., 2004. Identification of Emerging Human-Pathogenic Pythium insidiosum by serological and molecular assay based methods. J. Clin. Microbiol. 42, 3970-3974.

Walker, C.A., van West, P., 2007. Zoospore development in the oomycetes. Fungal Biol. Rev., 21, 1018.

Wanachiwanawin, W., Mendoza, L., Visuthisakchai, S., Mutsikapan, P., Sathapatayayongs, B., Suwanagool, P., Manuskiatti, W., Ruangsetakit, C., Ajello, L., 2004, Efficacy of immunotherapy using antigens of Pythium insidiosum in the treatment of vascular pythiosis in humans. Vaccine, 22, 3613-3621.

Wellahan, J.F., Farina, L.L., Keoughan, C.G., Lafortune, M., Grooters, A.M., Mendoza, L., Brown, M., Terrel, S.P., Jacobson, E.R., Heard, D.J., 2004. Pythiosis in a dromedary camel (Camelus dromedaries). J. Zoo Wildl. Med. 35, 564-568.

White, S.D., Ghoddusi, M., Grooters, A.M., Jones, K., 2008. Cutaneous pythiosis in a California nontravelled horse. Vet. Dermatol. 19, 391-394.

Witkamp, J., 1924. Bijdrage tot de kennis van de Hyphomycosis destruens. Ned. Ind. Blad voor Diergeneeskd. en Dierenteelt, 36, 229-245.

Witkamp, J. 1925. Het voorkomen van metastasen in de regionaire lymphlieren by Hyphomycosis destruens. Ned Ind Blad voor Diergeneeskd en Dierenteelt 37, 79-102.

\section{Legends to Figures}


Figure $1 \quad$ A five days old culture of Pythium insidiosum at $37^{\circ} \mathrm{C}$ grown on $2 \%$ Sabouraud dextrose agar (Panel A). P. insidiosum from plate cultures showing sparsely septate hyphae in lactophenol blue (20 X) (Panel B).

Figure 2 Fresh kunkers collected from a horse with cutaneous pythiosis. Kunkers are stony masses found only in horses with pythiosis. Note the different shapes developed in horses with pythiosis. Similar masses have been reported in equine habronemiasis. A differential diagnosis of habronemasias and pythiosis can be made by demonstration of sparsely septate hyaline hyphae within kunkers in the case of pythiosis.

Figure 3 Equine pythiosis can affect different areas of the skin (Panel A and B) and in chronic cases bones can also be invaded (Panel C).

Figure 4. In Panel A and B the clinical manifestation of cutaneous pythiosis in dogs is shown. In dogs this type of infection is very insidious and life threatening. Ulcerate granulomatous tissues, usually contaminated with bacteria are the main characteristic of dog pythiosis. Intestinal pythiosis is the most common type of infection in this species. In Panel C a duodenal tumoral-like mass from a dog with chronic gastro-intestinal tract pythiosis is shown (Courtesy of Dr. Y. Perazzo).

Figure 5. Pythiosis in cats occurs less frequent than in dogs and horses. The infection affects the subcutaneous tissue but rarely becomes ulcerate. The cat in the figure has a typical mass near the toraxic area caused by Pythium insidiosum (Courtesy of Dr. R.C. Thomas)

Figure 6. In Panels A and B two beef cattle with ulcerate tissue caused by Pythium insidiosum are shown. Note the swelling of the affected limb and the presence of some fistulae (Panel A) (Courtesy of Drs. R.C. Perez and J.J. Luis-Leon).

Figure 7. In Panel A a sheep with a strong inflammation of the face and bloody rhinorrhea caused by Pythium insidiosum is shown. In Panel B the location of the granulomatous tissue is inside the nostril passages (Courtesy of Drs. F. Riet-Correa and S.M.S. Silva).

Figure 8. A $10 \% \mathrm{KOH}$ wet mount preparation of a kunker from a horse. Panel A and B are the continuous microscopic field of the clinical sample. Note the long sparsely septate hyaline hyphae of Pythium insidiosum. The presence of numerous vesicles within the hyphae is usually observed.

Figure 9. Water cultures containing positive ions and grass leaves inoculated with Pythium insidiosum trigger the formation of sporangia containing zoospores. Sporangia are not differentiated from vegetative hyphae and are present inside the grass blades. Only a hypha-like discharge tube grows out through which the protoplasma is released in a thinwalled vesicle at the tip. Inside the vesicle the zoospores are differentiated. Zoospores are released after rupture of the vesicle membrane. Panel A: the vesicles with zoospores that developed after three hours incubation. Panel B: a close-up of a vesicle before zoospore release. Below the vesicle the empty discharge tube is visible.

Figure 10. Panels A and B are H\&E histological preparations showing a granulomatous reaction with numerous eosinophils, giant cells, mast cells and other cells from an intestinal case of dog pythiosis. Panel B: unstained hyphae of Pythium insidiosum (arrow, 40X). Panels 
$1030 \mathrm{C}(20 \mathrm{X})$ and D (50X) are a Silver stain preparation of the same tissue. Note the presence of 1031 numerous none septate hyphae, some forming rounded shape structures.

Figure 11. The right section of the figure shows the inflammatory response of a host naturally exposed to Pythium insidiosum. In this scenario, zoospores (or other propagules) of $P$. insidiosum attach to the injured skin of a host; the encysted zoospore stimulated by the host's temperature develops a germ tube that actively penetrates the host tissue causing the infection. As the hypha develops it releases exoantigens that are presented to the host immune system. The antigen presenting cells (APC) will process the immunogens and by releasing IL4 the Th0 naïve cells become Th2. The stimulated Th2 subset will then release IL4, IL5, and IL10, which in turn stimulates B cells to produce precipitating $\operatorname{IgG}, \operatorname{IgM}$ and $\operatorname{IgE}$ molecules. IgE along with IL5 triggers the migration of mast cells and eosinophils to the site of infection that later degranulate over the $P$. insidiosum hyphae causing tissue damage in the infected host. The left side of the figure depicts the putative response to $P$. insidiosum immunogens after immunotherapy. Upon injection the immunogens are presented to APC in a different fashion than during natural infection. The Th0 naïve cells turn into Th1 releasing IFN $\gamma$ and IL2 stimulating the cell mediate immunity (CMI) and cytotoxic lymphocytes (CTL) that eventually could eliminate the pathogen from the infected tissues. Experimental evidence suggests that this strategy could protect the host for short periods of time (one year) by stimulating B cells to produce protective IgG classes. 


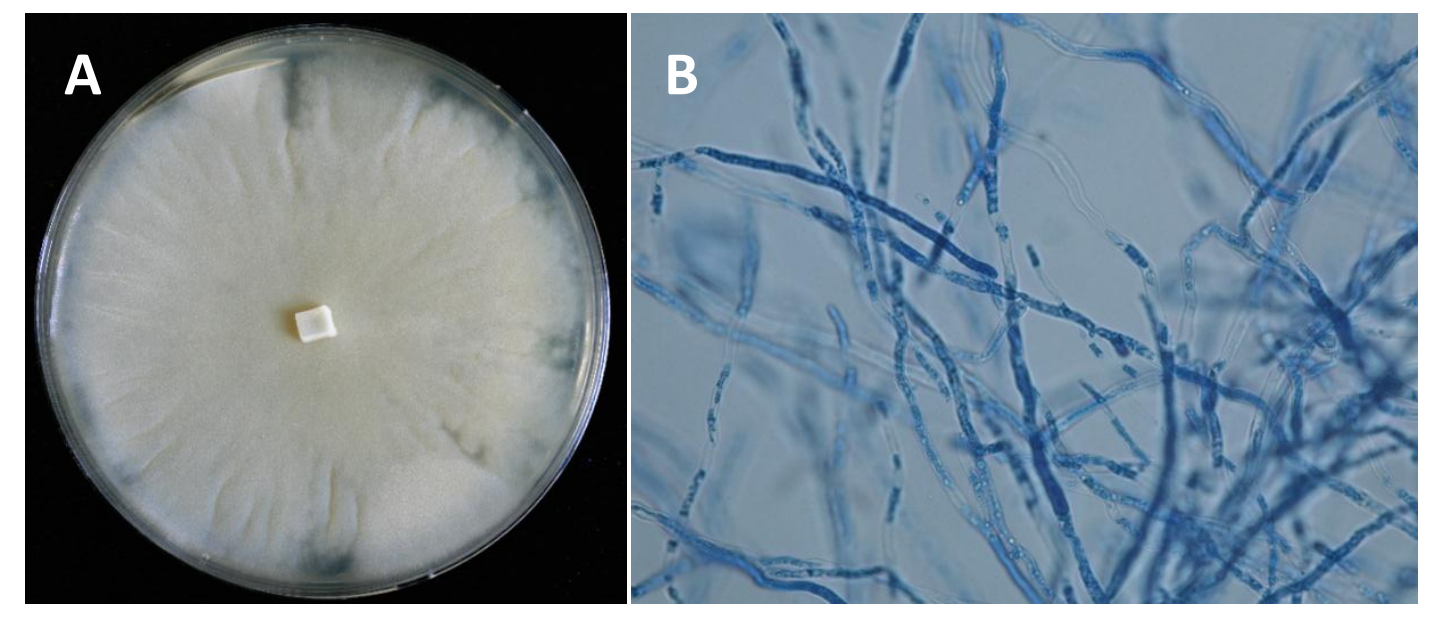

Figure 1 


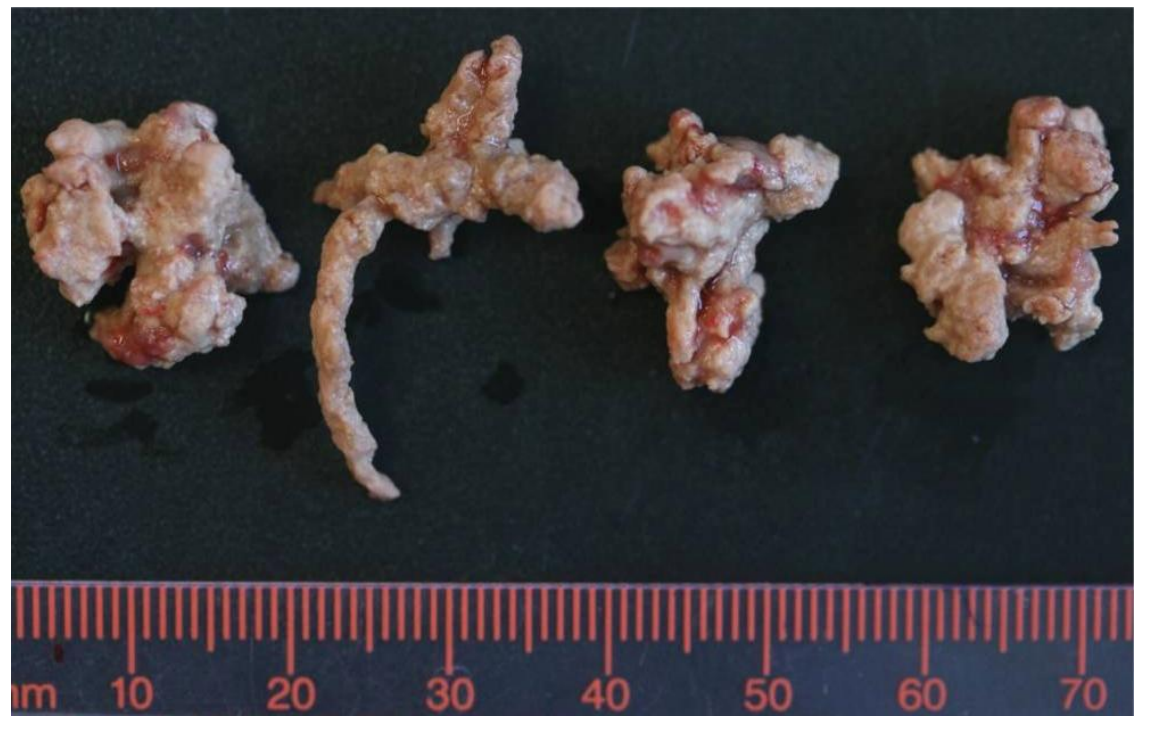

Figure 2 


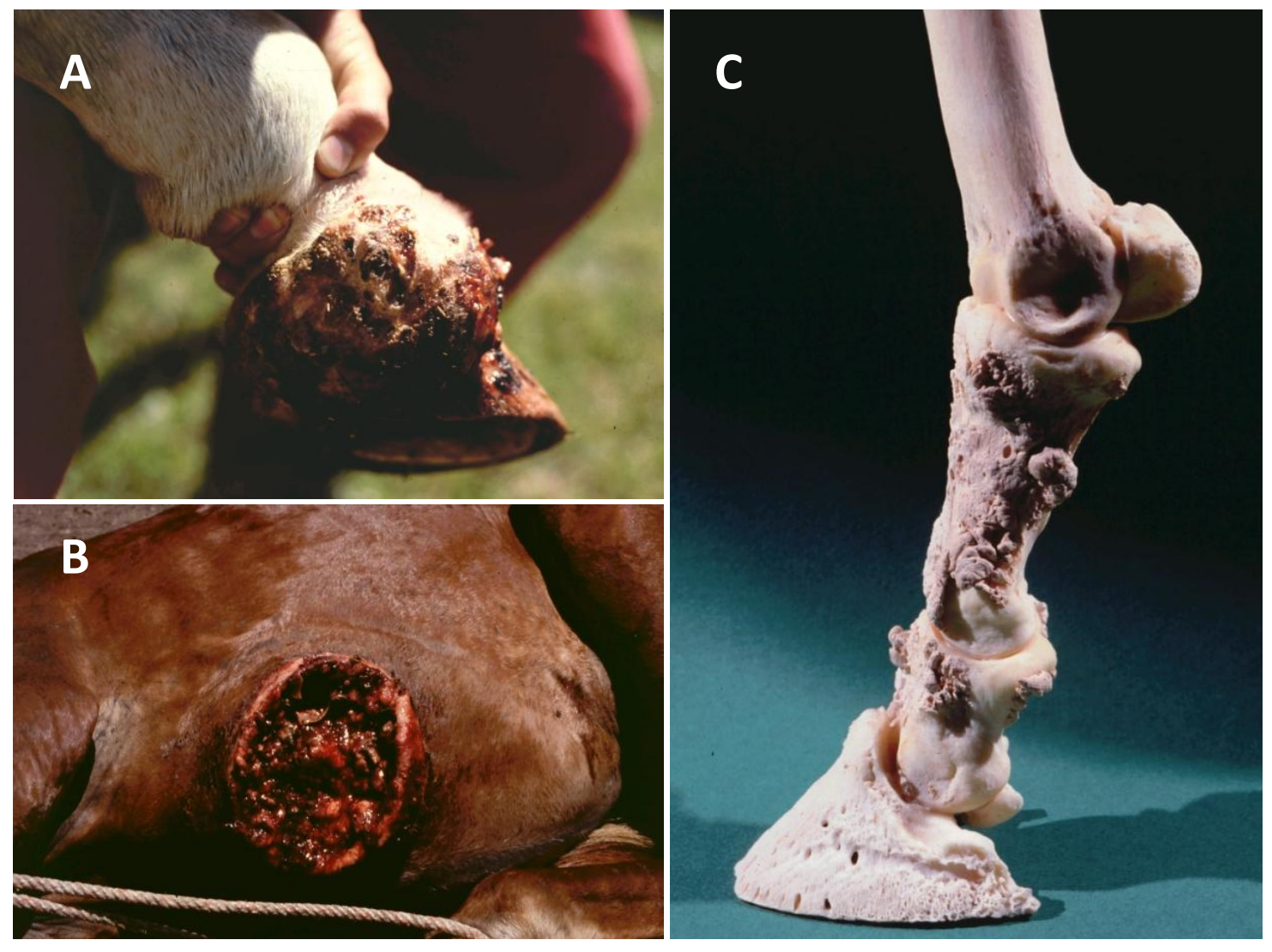

Figure 3 


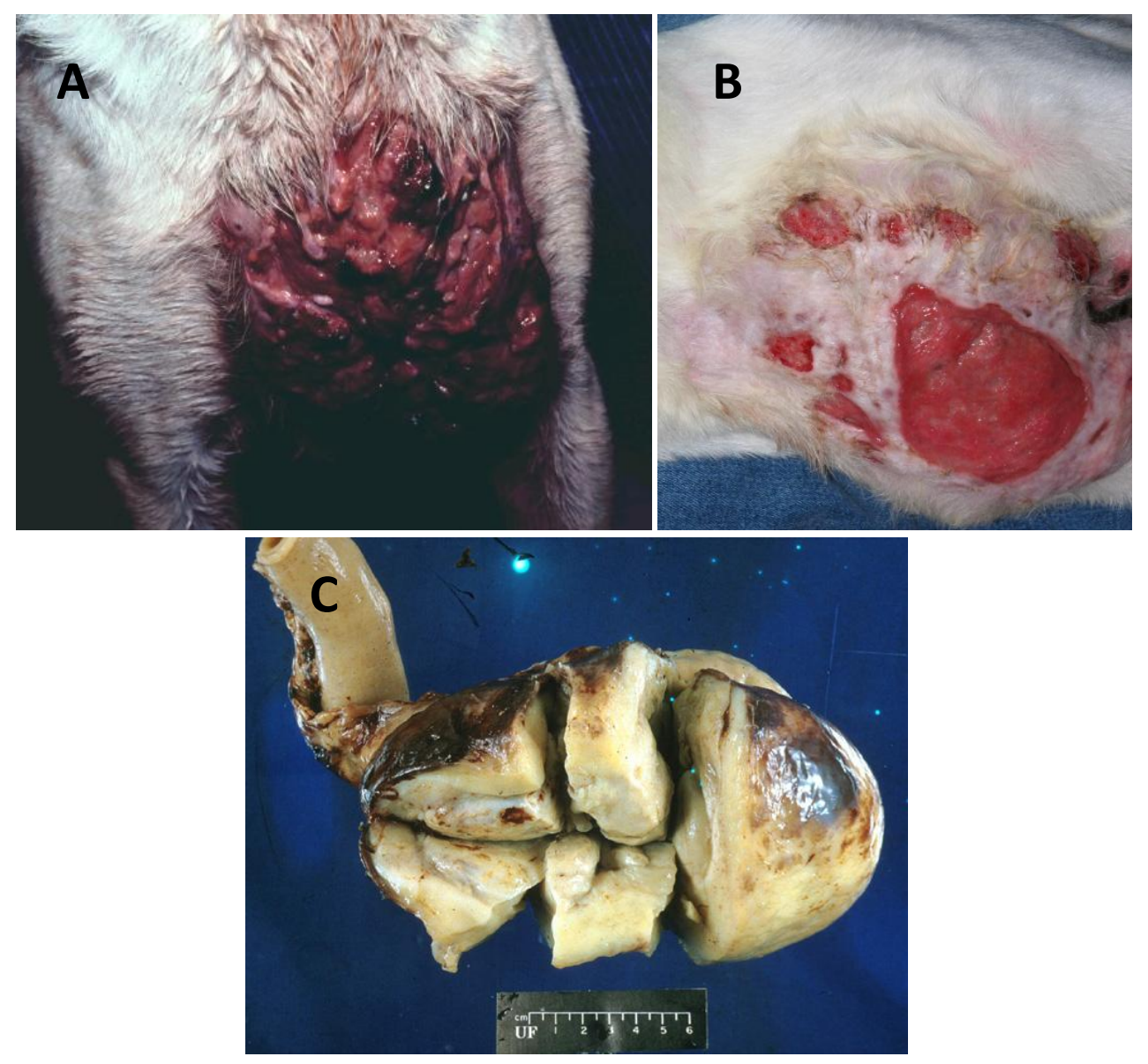

Figure 4 


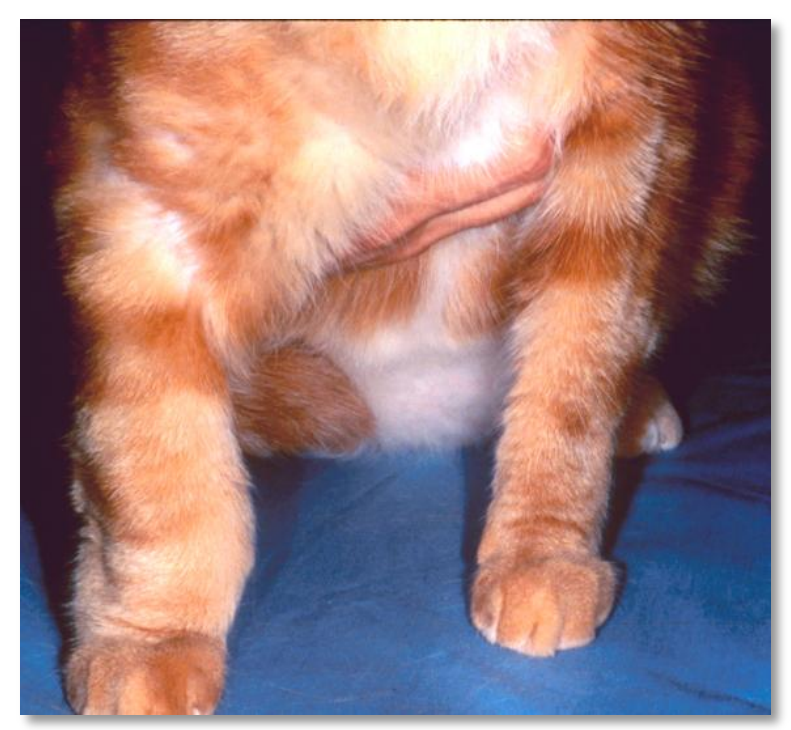

Figure 5 


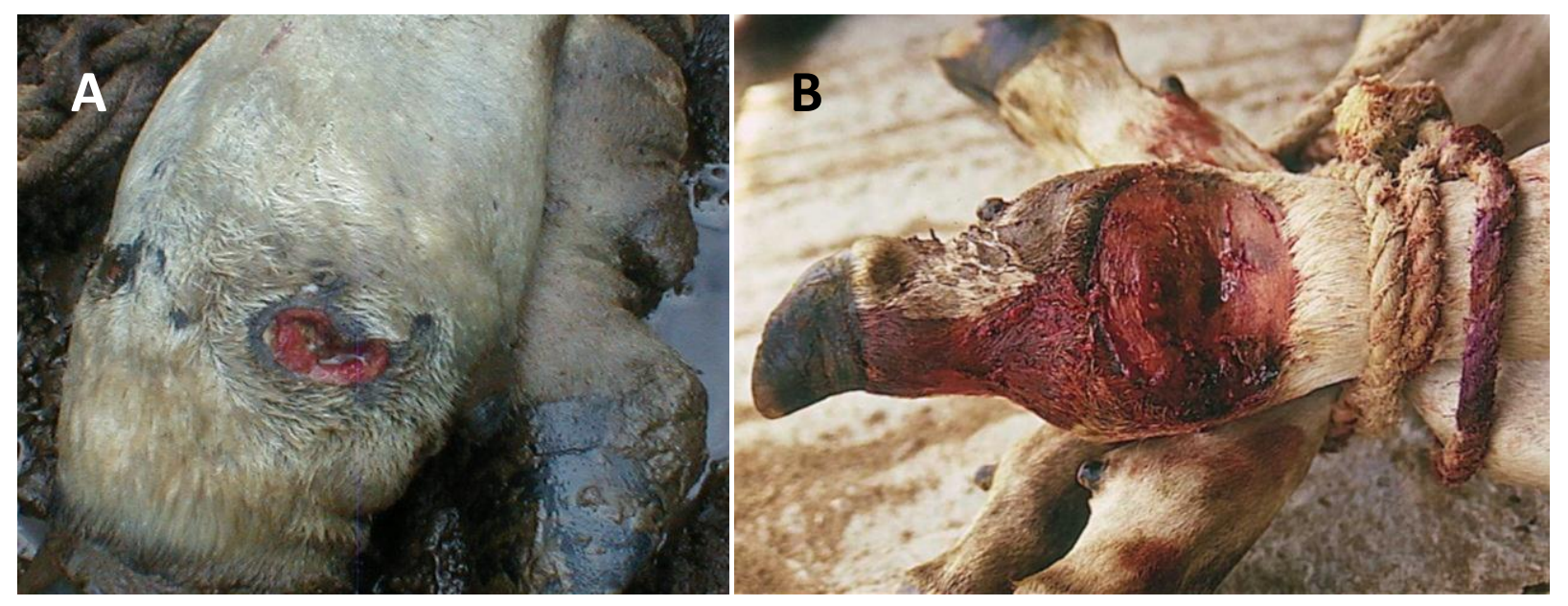

Figure 6 


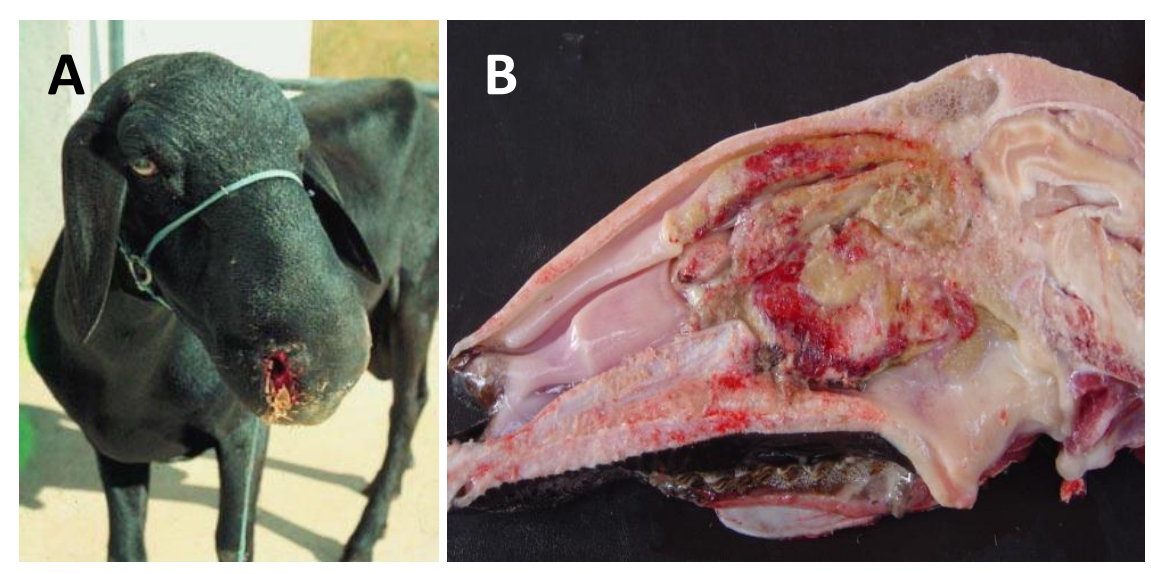

Figure 7 


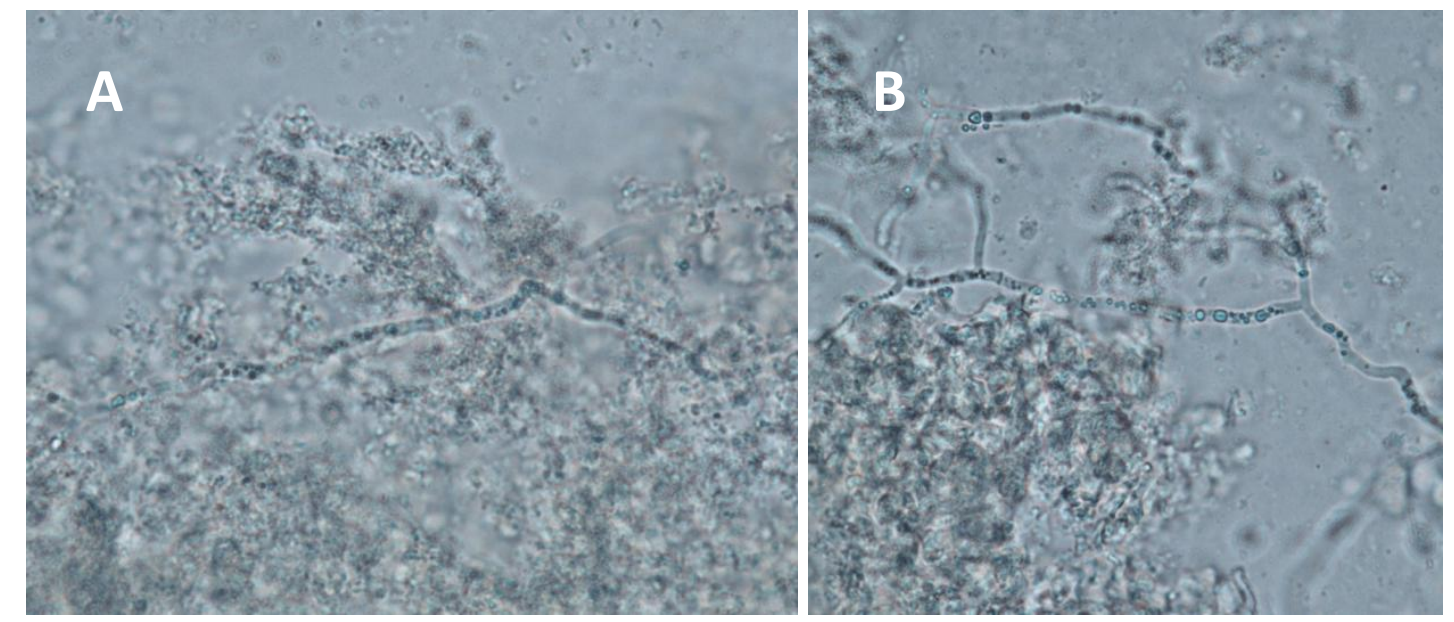

Figure 8 


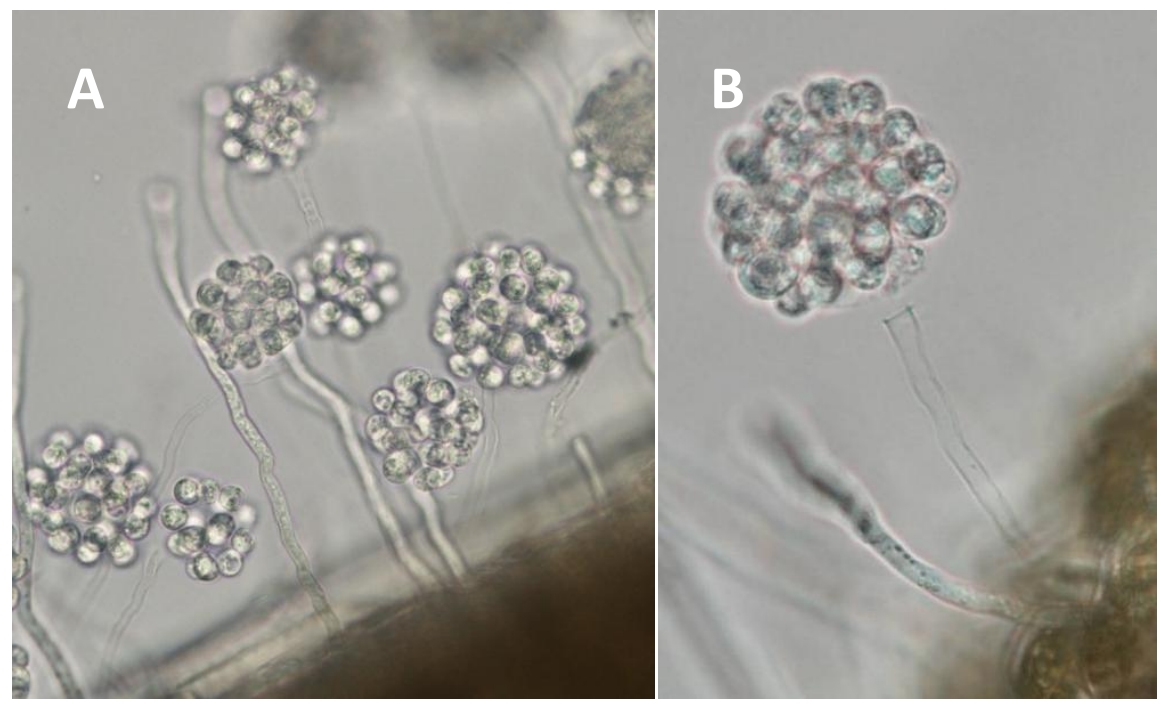

Figure 9 


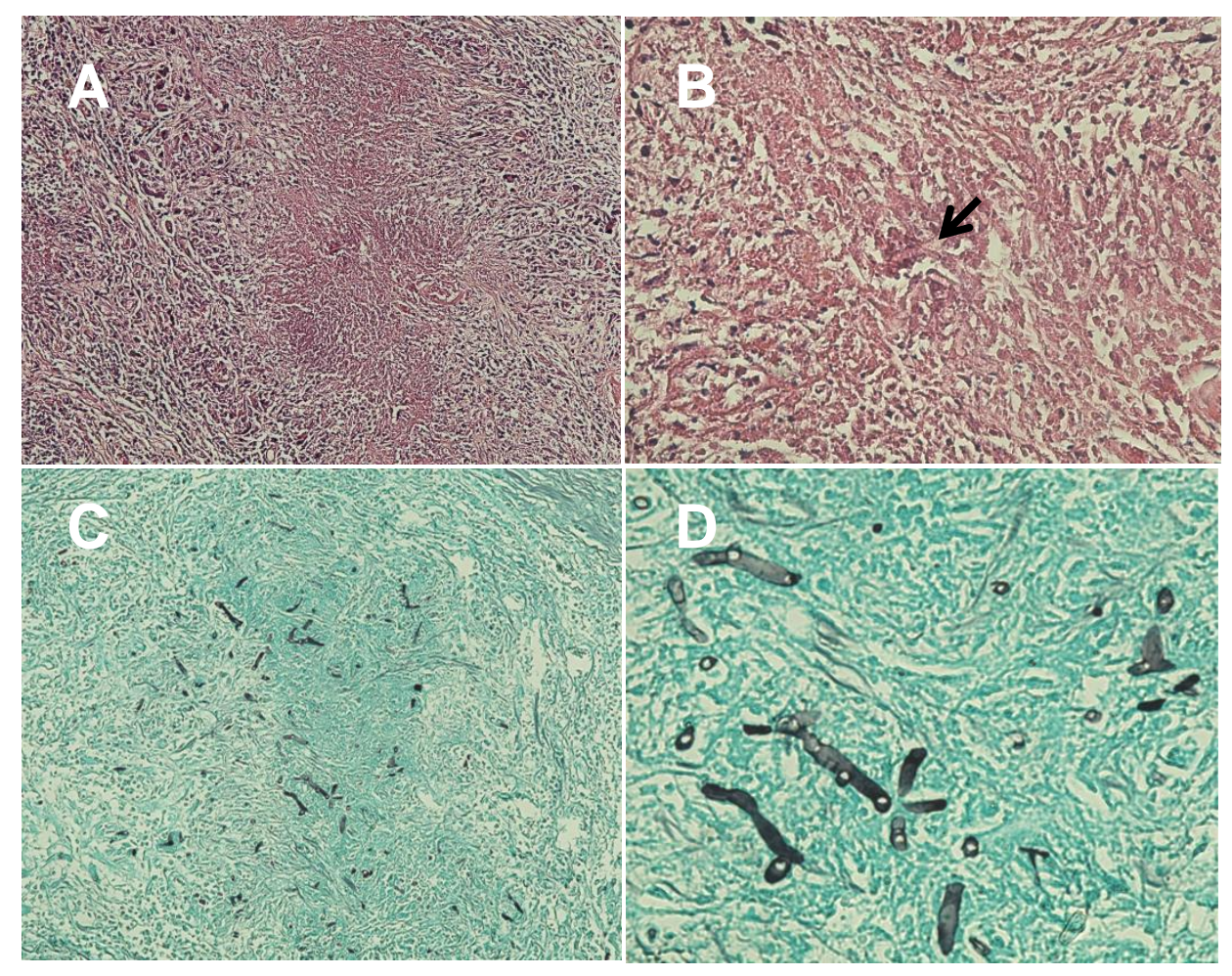

Figure 10 


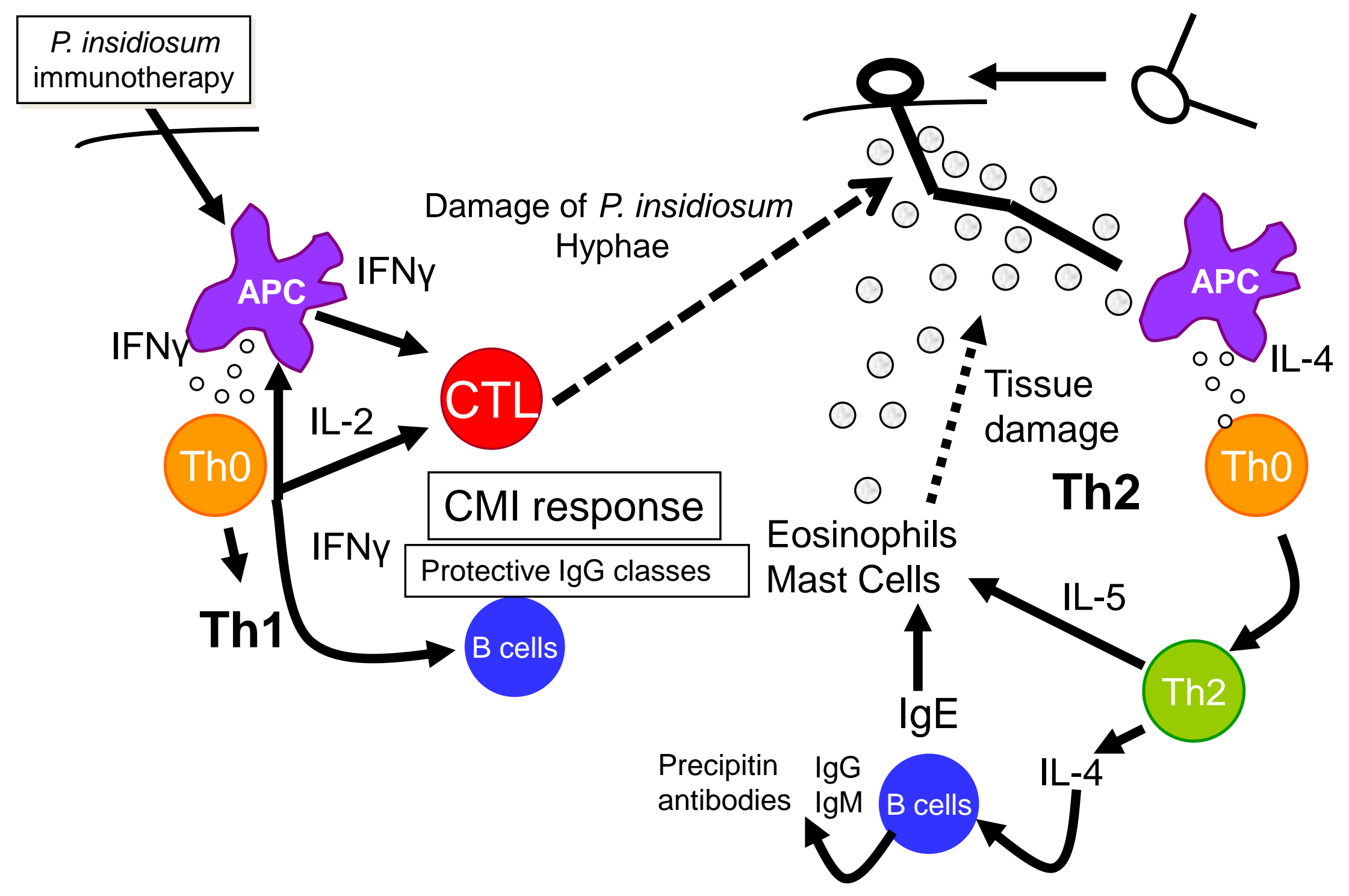

Figure 11 Redrawn after Mendoza and Newton, 2005 